\title{
Secondary arsenic minerals from the Złoty Stok As-Au abandoned mine (SW Poland)
}

\author{
Rafał SIUDA ${ }^{1, *}$ and Anna MACIOCH ${ }^{1}$ \\ 1 University of Warsaw, Institute of Geochemistry, Mineralogy and Petrology, Żwirki i Wigury 93, 02-089 Warszawa, Poland
}

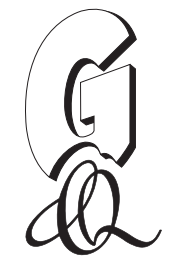

Siuda R., Macioch, A., 2018. Secondary arsenic minerals from the Złoty Stok As-Au abandoned mine (SW Poland). Geological Quarterly, 62 (4): 925-940, doi: 10.7306/gq.1442

Associate editor: Stanisław Wołkowicz

Secondary arsenic minerals (SAM) formed recently in abandoned adits of the former Au-As mine at Złoty Stok (SW Poland) constitute two assemblages. The first consists of two types of scorodite, pitticite, kaňkite, hörnesite, picropharmacolite and minor amounts of jarosite and gypsum. Formation of the Fe arsenates took place under acidic conditions $(\mathrm{pH} \sim 3-4)$ as a result of löllingite, arsenopyrite and pyrite oxidation. Hörnesite and picropharmacolite crystallized as products of interactions between acidic arsenic-rich pore solutions with $\mathrm{Mg}$-Ca carbonates from rocks that surround the ore mineralisation. The interaction of carbonates with acid pore solutions caused a rapid increase in $\mathrm{pH}$ that reached neutral or weakly alkaline values. The chemical compositions of hörnesite and picropharmacolite correspond well to their ideal compositions: $\left(\mathrm{Mg}_{3.17} \mathrm{Ca}_{0.07}\right)_{\Sigma 3.24}\left(\mathrm{AsO}_{4}\right)_{1.90} \cdot 8 \mathrm{H}_{2} \mathrm{O}$ and $\mathrm{Ca}_{4.31} \mathrm{Mg}_{0.92}\left(\mathrm{HAsO}_{4}\right)_{1.91}\left[\left(\mathrm{AsO}_{4}\right)_{1.99}\left(\mathrm{SO}_{4}\right)_{0.01}\right]_{\Sigma 2.00} \cdot 11 \mathrm{H}_{2} \mathrm{O}$, respectively. The second assemblage of SAM comprises exclusively the Mg-enriched erythrite $\left.\left[\left(\mathrm{Co}_{1.66} \mathrm{Mg}_{1.03} \mathrm{Ni}_{0.28} \mathrm{Ca}_{0.05} \mathrm{Zn}_{0.02}\right)_{\Sigma 3.03}\left(\mathrm{AsO}_{4}\right)_{1.99} \cdot 8 \mathrm{H}_{2} \mathrm{O}\right)\right]-$ annabergite $\left[\left(\mathrm{Ni}_{1.48} \mathrm{Mg}_{0.94} \mathrm{Co}_{0.66} \mathrm{Ca}_{0.12} \mathrm{Fe}_{0.01} \mathrm{Zn}_{0.01}\right)_{\Sigma 3.20}\left(\mathrm{AsO}_{4}\right)_{1.92} \cdot 8 \mathrm{H}_{2} \mathrm{O}\right]$ series. These minerals crystallized from slightly acidic ( $\mathrm{pH} \sim 5-6)$ to neutral media. Dissolution of SAM and other secondary phases (e.g., schwertmannite) causes the release of arsenate and sulphate ions into mine waters. These ions can be reduced under anaerobic conditions by different strains of bacteria. The product of this process is orpiment.

Key words: erythrite-hörnesite-annabergite series, picropharmacolite, secondary arsenic minerals.

\section{INTRODUCTION}

Arsenic is an example of toxic element released during decomposition of its primary minerals. Secondary arsenic minerals (SAM) are among the main As sinks in the supergene environment. Their crystallisation strongly depends on the physicochemical properties of the weathering zones of As-rich deposits (e.g., Drahota and Filippi, 2009). Changes in these conditions lead to the dissolution of SAM. This process releases arsenic into underground and surface waters, thus leading to their contamination (Marszałek and Wąsik, 2000). Particular species of SAM are well-studied because of arsenic toxicity, which strongly depends on the oxidation state of this metalloid. Thus, understanding SAM stability plays an important role from the environmental point of view. Secondary phases from the Złoty Stok deposit have been poorly recognized in previous research. Only several weathering minerals are known from this locality (Kubisz, 1964; Budzyńska, 1971). This paper is the first to presents the results of detailed study

\footnotetext{
* Corresponding author, e-mail: siuda@uw.edu.pl Received: February 15, 2018; accepted: October 30, 2018; first published online: December 18, 2018
}

of recently forming SAM found within abandoned adits of the Au-As mine at Złoty Stok. Attention is paid to the chemical diversity of SAM and their relationships to the known crystallochemical solid solutions. We also reconstruct the crystallisation conditions of the SAM under study.

\section{GEOLOGY}

The Złoty Stok Au-As deposit is located in the central part of the Lower Silesian Block (Żelaźniewicz et al., 2011) at the contact between the Złoty Stok-Skrzynka Shear Zone and the Kłodzko-Złoty Stok granitoid pluton. The Złoty Stok-Skrzynka Shear Zone developed during Variscan deformation of different metamorphic rocks (Cymerman, 1996; Mazur et al., 2006). It is composed of blastomyllonites, gneisses, mica schists and leptinites intercalated with marbles, amphibolites and serpentinites; the latter coexisting with minor nephrites (Kowalski, 1969; Smulikowski, 1979; Gil et al., 2015; Fig. 1). The Kłodzko-Złoty Stok granitoid pluton consists of rocks ranging from granodiorite to monzonite (Mikulski et al., 2013; Mikulski and Williams, 2014). Different types of hornfelses, skarns and skarnoids have been formed in the granitoid contact zone due to the thermal and metasomatic influence of the pluton (Wierzchołowski, 1976). Metasomatic events related to the Variscan magmatism 


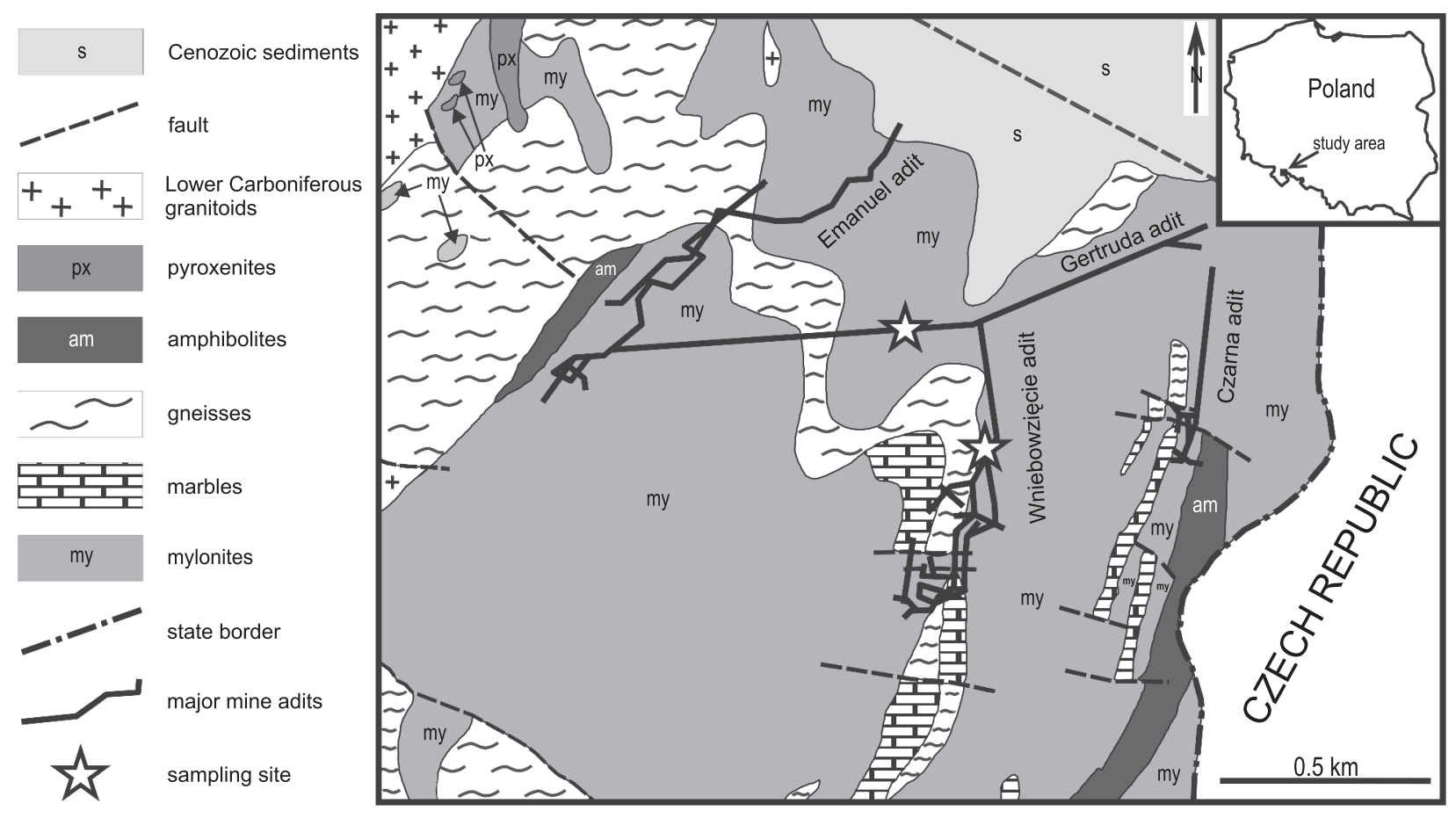

Fig. 1. Geological map of the Złoty Stok area, modified after Cwojdziński (1974); location of adits is based on old mining maps

were also responsible for the main ore mineralization in the Złoty Stok deposit (Mikulski and Speczik, 2008, 2016).

Three types of ore mineralisation occur in the Złoty Stok Au-As deposit. The first type contains löllingite-arsenopyrite mineralisation associated with diopside skarns and serpentinites surrounding dolomitic marbles. The second type is a pyrrhotite-magnetite ore with minor löllingite and arsenopyrite residing within diopside-tremolite rocks. The third variety is a disseminated löllingite-arsenopyrite ore that occurs inside black serpentinite. Sub-microscopic and microscopic gold occurs in all the ore types (Mikulski and Speczik, 2016). Other ore minerals, such as pyrite, galena, sphalerite, chalcopyrite, scheelite, glaucodot, cobaltite, cubanite, marcasite, bismuthinite, bismuth, arsenic, and $\mathrm{Ni}-\mathrm{Fe}-\mathrm{Co}$ sulphoarsenides occur as small aggregates of no economic significance (Mikulski, 1996; Muszer, 2011).

The Złoty Stok deposit has a long mining history. The first information about gold mines dates back to 1341 in this area (Dziekoński, 1972). Production of arsenic and synthetic arsenic pigments started at the beginning of the 17th century. Due to the poor quality of the arsenic ores, mining and arsenic-gold smelter activity ceased in 1961 (Muszer, 2011).

\section{METHODS AND SAMPLES}

Mineral samples were collected from the Gertruda and Wniebowzięcie adits of the former Au-As Złoty Stok mine (Fig. 1). The most diverse supergene mineralisation was found in the Gertruda adit ( $~ 842 \mathrm{~m}$ from the entrance). A small, up to $30 \mathrm{~cm}$ in size, ore lens surrounded by barren rocks rich in calcite and dolomite, was found there. The primary minerals of this lens (löllingite, arsenopyrite and pyrite) have been almost completely decomposed by weathering, leading to the formation of several characteristic zones with different mineral compositions
(Fig. 2). The first, central zone is dominated by powdery scorodite that contains relicts of the ore minerals. In the marginal parts of this scorodite type occurs its second form represented by botryoidal or spherical green aggregates. It is followed by pitticite, next to which the kaňkite accumulation zone is found. Segregations of $\mathrm{Mg}$ and $\mathrm{Ca}$ arsenates occur in the barren rocks surrounding the ore lens. In this zone, large amounts of biofilms with colonies of microorganisms are seen. The other mineral samples were taken from the Wniebowzięcie adit, which is situated to the south of the Gertuda adit. Co-Mg-Ni arsenates form small aggregates on the surface of the weathering Co-rich löllingite. In Wniebowzięcie adit, schwertmannite was also found; however, it does not occur with SAM. The samples vary from 0.5 to $10 \mathrm{~cm}$ in diameter. To avoid humidity changes, all mineral samples were placed in tightly-sealed plastic containers. The samples were transported to the laboratory and stored at a temperature of about $+10^{\circ} \mathrm{C}$.

Quantitative chemical data were acquired using a Cameca SX 100 electron microprobe of the Inter-Institute Analytical Complex from Minerals and Synthetic Substances, University of Warsaw. The following standards, analytical lines and crystals were used: $\mathrm{V}_{2} \mathrm{O}_{5}-\mathrm{V}(\mathrm{K} \alpha$, LIF), rhodochrosite $-\mathrm{Mn}(\mathrm{K} \alpha$, LIF), $\mathrm{Fe}_{2} \mathrm{O}_{3}-\mathrm{Fe}(\mathrm{K} \alpha, \mathrm{LIF})$, chalcopyrite - $\mathrm{Cu}(\mathrm{K} \alpha$, LIF), ZnS -

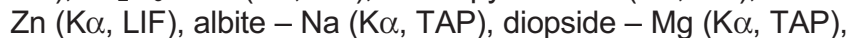

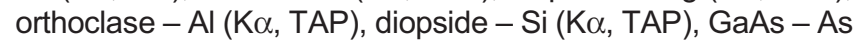

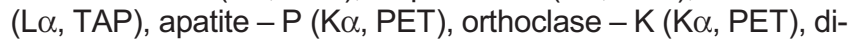
opside - Ca (K $\alpha, \mathrm{PET}), \mathrm{NiO}-\mathrm{Ni}(\mathrm{K} \alpha$, LIF), and metallic Co - Co $(\mathrm{K} \alpha$, LIF). Analyses were conducted using the accelerating voltage of $10 \mathrm{kV}$ and beam current of $5 \mathrm{nA}$. The beam diameter was 5-10 $\mu \mathrm{m}$. ZAF corrections were applied. Elevated analytical totals for minerals with hydroxyl groups or crystallisation water are generally caused by evaporation of water under high vacuum conditions or by its evaporation due to heating of the analysed area by the electron beam. Lower totals are due to the porous nature of some minerals. The presence of all minerals was con- 


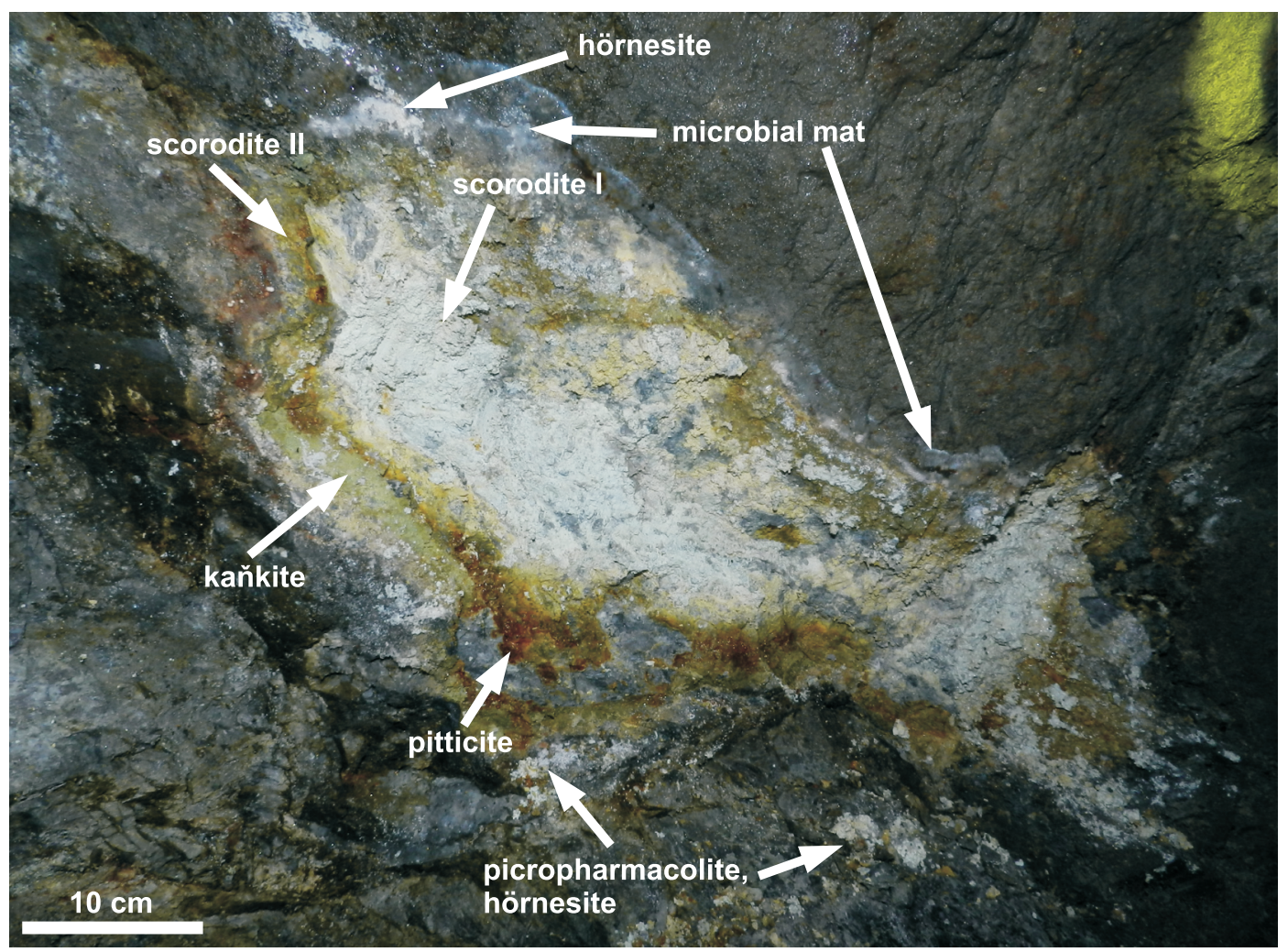

Fig. 2. Secondary Fe and Mg-Ca arsenates on the wall of the Gertruda adit

firmed by powder X-Ray diffraction (PXRD). Identification of those minerals was performed using a powder $X$-ray diffractometer X'Pert PRO MPD by the DSH method. The parameters of the X-ray beam were as follows: CoK $\alpha$ wavelength, finally monochromatized by parabolic X-rays mirrors, emitted from the $\mathrm{X}$-Ray tube with $40 \mathrm{~mA}$ and $40 \mathrm{kV}$ current applied. X-ray patterns were recorded in 2.5 to $75.99{ }^{\circ} 2 \theta$ range, with a step size of $0.02^{\circ} 2 \theta$. The results were processed using the X-ray analysis software $X$ 'Pert Plus HighScore (ver. 2.2e) and ICDD $P D F-2$ database. Morphology of the samples was studied at the Faculty of Geology, University of Warsaw, using a FE-SIGMA VP (Carl Zeiss Microscopy $\mathrm{GmbH}$ ) scanning electron microscope with an energy-dispersive (EDS) detector (Quantax XFlash 310, Bruker Nano $\mathrm{GmbH}$ ). IR absorption spectra were recorded with a Nicolet Magna 550 specrometer from 4000 to $400 \mathrm{~cm}^{-1}$, using KBr pellets (Faculty of Chemistry, Warsaw University). Raman spectra were recorded on a Jobin spectrometer -Yvone-Horiba coupled with a confocal microscope Olympus BX40 (AGH University of Science and Technology). The spectra were collected from mineral samples at room temperature, using laser with a wavelength of $514.5 \mathrm{~nm}$ in the range of $4000-50 \mathrm{~cm}^{-1}$ at a resolution of $3.5 \mathrm{~cm}^{-1}$ and a measurement time from 30 to $360 \mathrm{~s}$.

\section{SECONDARY MINERALS FROM THE GERTRUDA ADIT}

\section{SCORODITE $\mathrm{FeAsO}_{4} \cdot 2 \mathrm{H}_{2} \mathrm{O}$}

In the Gertruda adit, this mineral forms two types of aggregate. The first is powdery and grey-green and occurs in the cen- tral part of the strongly oxidized ore lens, almost completely replacing the primary löllingite-arsenopyrite-pyrite aggregates. The diameter of these type-I scorodite aggregates reaches tens of centimetres. Even by applying very large magnifications, no crystals of this mineral can be observed. The chemical composition of the type-I scorodite does not strongly differ from the theoretical composition (Table 1). The iron content varies from 0.84 to $0.99 \mathrm{apfu}$. This element is replaced by a small amount of aluminum (0.01-0.08 apfu) and magnesium (up to $0.02 \mathrm{apfu}$ ). In the tetrahedral site the arsenate ion (0.66-0.99 apfu) is replaced by sulphate anion ( $0.02-0.28 \mathrm{apfu}$ ) accompanied by a phosphate ion (0.01 apfu). The calculated empirical formula of the type-I scorodite (based on four oxygen atoms per formula unit) is $\left(\mathrm{Fe}_{0.92} \mathrm{Al}_{0.02}\right)_{\Sigma 0.94}\left[\left(\mathrm{AsO}_{4}\right)_{0.75}\left(\mathrm{SO}_{4}\right)_{0.22}\left(\mathrm{PO}_{4}\right)_{0.01}\right]_{\Sigma 0.98} \cdot 2 \mathrm{H}_{2} \mathrm{O}$. The second type of scorodite (scorodite II) forms green spherical aggregates up to $100 \mu \mathrm{m}$ in diameter (Fig. 3A). They appear outside the earthly scorodite and coexist with pitticite. The identification of the scorodite II was based only on the PXRD method (Fig. 4A).

\section{KAŇKITE $\mathrm{FeAsO}_{4} \cdot 3.5 \mathrm{H}_{2} \mathrm{O}$}

Kaňkite is another iron arsenate. It forms semi-crystalline green coatings on the barren rock surface. These encrustations are built of very fine, thin tabular crystals up to $20 \mu \mathrm{m}$ in size (Fig. 5A). The chemical composition of kaňkite is shown in Table 2. It shows a relatively small variation in iron content (from 0.88 to $0.98 \mathrm{apfu}$ ). This element is accompanied by aluminum (from 0.04 to $0.14 \mathrm{apfu}$ ) and magnesium (from 0.01 to 0.03 apfu). The arsenate content varies from 0.86 to $0.97 \mathrm{apfu}$. This anion is substituted to a small extent by sulphate (from 0.01 to $0.04 \mathrm{apfu})$ and phosphate (0.01 apfu) ions. Based on mi- 
Chemical composition [wt.\%] of type-I scorodite from the Gertruda adit

\begin{tabular}{|c|c|c|c|c|c|c|c|c|c|c|}
\hline $\begin{array}{l}\text { Analysis } \\
\text { number }\end{array}$ & 1 & 2 & 3 & 4 & 5 & 6 & 7 & 8 & 9 & 10 \\
\hline $\mathrm{Fe}_{2} \mathrm{O}_{3}$ & 29.73 & 30.56 & 36.01 & 36.93 & 37.12 & 35.02 & 36.26 & 34.04 & 34.63 & 35.13 \\
\hline $\mathrm{Al}_{2} \mathrm{O}_{3}$ & 1.78 & 1.80 & 0.16 & 0.17 & 0.19 & 0.20 & 0.19 & 0.20 & 0.18 & 0.22 \\
\hline $\mathrm{MnO}$ & 0.00 & 0.00 & 0.03 & 0.00 & 0.00 & 0.14 & 0.00 & 0.00 & 0.00 & 0.00 \\
\hline $\mathrm{MgO}$ & 0.39 & 0.37 & 0.00 & 0.00 & 0.00 & 0.00 & 0.00 & 0.00 & 0.00 & 0.00 \\
\hline $\mathrm{As}_{2} \mathrm{O}_{5}$ & 49.68 & 50.80 & 38.40 & 37.68 & 35.49 & 37.21 & 38.01 & 39.00 & 39.04 & 38.51 \\
\hline $\mathrm{SO}_{3}$ & 1.34 & 0.89 & 9.75 & 10.24 & 10.44 & 10.65 & 9.93 & 10.51 & 10.25 & 10.22 \\
\hline $\mathrm{P}_{2} \mathrm{O}_{5}$ & 0.38 & 0.35 & 0.15 & 0.16 & 0.15 & 0.14 & 0.18 & 0.16 & 0.13 & 0.17 \\
\hline $\mathrm{SiO}_{2}$ & 0.00 & 0.04 & 0.12 & 0.09 & 0.08 & 0.06 & 0.11 & 0.07 & 0.08 & 0.08 \\
\hline $\mathrm{H}_{2} \mathrm{O}_{*}$ & 15.90 & 16.11 & 17.04 & 17.21 & 16.88 & 16.94 & 17.08 & 17.08 & 17.08 & 17.08 \\
\hline Total & 99.20 & 100.92 & 101.66 & 102.47 & 100.36 & 100.35 & 101.76 & 101.06 & 101.40 & 101.40 \\
\hline \multicolumn{11}{|c|}{ apfu } \\
\hline $\mathrm{Fe}^{3+}$ & 0.84 & 0.86 & 0.95 & 0.97 & 0.99 & 0.93 & 0.96 & 0.90 & 0.91 & 0.93 \\
\hline $\mathrm{Al}^{3+}$ & 0.08 & 0.08 & 0.01 & 0.01 & 0.01 & 0.01 & 0.01 & 0.01 & 0.01 & 0.01 \\
\hline $\mathrm{Mn}^{2+}$ & 0.00 & 0.00 & 0.00 & 0.00 & 0.00 & 0.00 & 0.00 & 0.00 & 0.00 & 0.00 \\
\hline $\mathrm{Mg}^{2+}$ & 0.02 & 0.02 & 0.00 & 0.00 & 0.00 & 0.00 & 0.00 & 0.00 & 0.00 & 0.00 \\
\hline$\Sigma$ A side & 0.94 & 0.96 & 0.96 & 0.98 & 1.00 & 0.95 & 0.97 & 0.91 & 0.92 & 0.94 \\
\hline $\mathrm{AsO}_{4}^{3-}$ & 0.98 & 0.99 & 0.71 & 0.69 & 0.66 & 0.69 & 0.70 & 0.72 & 0.72 & 0.71 \\
\hline $\mathrm{SO}_{4}^{2-}$ & 0.04 & 0.02 & 0.26 & 0.27 & 0.28 & 0.28 & 0.26 & 0.28 & 0.27 & 0.27 \\
\hline $\mathrm{PO}_{4}^{3-}$ & 0.01 & 0.01 & 0.00 & 0.00 & 0.00 & 0.00 & 0.01 & 0.00 & 0.00 & 0.01 \\
\hline $\mathrm{SiO}_{4}^{4}$ & 0.00 & 0.00 & 0.00 & 0.00 & 0.00 & 0.00 & 0.00 & 0.00 & 0.00 & 0.00 \\
\hline$\Sigma T$ side & 1.03 & 1.03 & 0.97 & 0.96 & 0.94 & 0.98 & 0.97 & 1.00 & 0.99 & 0.98 \\
\hline $\mathrm{H}_{2} \mathrm{O}$ & 2.00 & 2.00 & 2.00 & 2.00 & 2.00 & 2.00 & 2.00 & 2.00 & 2.00 & 2.00 \\
\hline
\end{tabular}

${ }^{*} \mathrm{H}_{2} \mathrm{O}$ was calculated from the ideal content in the formula $\mathrm{H}_{2} \mathrm{O}=2 ; \mathrm{Ca}, \mathrm{Ni}, \mathrm{Co}, \mathrm{V}$ below detection limit

cro-area analyses, the empirical formula of kaňkite (calculated based on four oxygen atoms) is $\left(\mathrm{Fe}_{0.93} \mathrm{Al}_{0.08} \mathrm{Mg}_{0.02} \mathrm{Ca}_{0.01}\right)_{\Sigma}$ ${ }_{1.05}\left[\left(\mathrm{AsO}_{4}\right)_{0.93}\left(\mathrm{SO}_{4}\right)_{0.03}\left(\mathrm{PO}_{4}\right)_{0.01}\right]_{\Sigma 0.97} \cdot 3.50 \mathrm{H}_{2} \mathrm{O}$. The presence of kaňkite was confirmed by the PXRD method (Fig. 4B).

\section{PITTICITE}

Pitticite appears between scorodite II and kaňkite. It occurs as honey-yellow or brownish crust-like aggregates with a distinctive conchoidal fracture and vitreous to greasy luster (Fig. $3 \mathrm{~B}$ ). It is also very brittle and strongly cracked. The chemical composition is shown in Table 3. The iron content varies from 33.15 to 36.92 wt. $\% \mathrm{Fe}_{2} \mathrm{O}_{3}$. Small amounts of aluminum (from 0.20 to 0.31 wt. $\% \mathrm{Al}_{2} \mathrm{O}_{3}$ ) and magnesium (up to 0.09 wt. $\%$ $\mathrm{MgO}$ ) were also detected. Arsenic, ranging in content from 36.72 to 39.95 wt. $\% \mathrm{As}_{2} \mathrm{O}_{5}$, is accompanied by sulphur (10.45 to 11.36 wt. $\% \mathrm{SO}_{3}$ ), phosphorus (from 0.09 to 0.26 wt. $\% \mathrm{P}_{2} \mathrm{O}_{5}$ ) and silicon (up to 0.06 wt. $\% \mathrm{SiO}_{2}$ ).

\section{HÖRNESITE $\mathrm{Mg}_{3}\left(\mathrm{AsO}_{4}\right)_{2} \cdot 8 \mathrm{H}_{2} \mathrm{O}$}

Hörnesite crystallises on barren rock surfaces (Mg-enriched marble) on the outside of the kankkite accumulations zone. It forms very fine, white, spherical aggregates up to $4 \mathrm{~mm}$ in size (Fig. 3C). Snowball-like aggregates of hörnesite are built of automorphic lath-like crystals. The size of the crystals is up to
$20 \mu \mathrm{m}$. At large magnifications, a mosaic structure of the crystal terminations is visible (Fig. 5B). Hörnesite aggregates are usually surrounded by mucous products of microbiological metabolism processes (Fig. 5C). The chemical composition of hörnesite from the Gertruda adit is also close to the theoretical value (Table 4). There is only a small amount of calcium. The chemical analysis of hörnesite yields the formula $\left(\mathrm{Mg}_{3.17} \mathrm{Ca}_{0.07}\right)_{\Sigma}$ ${ }_{3.24}\left(\mathrm{AsO}_{4}\right)_{1.90} \cdot 8 \mathrm{H}_{2} \mathrm{O}$ (calculated based on eight oxygen atoms). The Raman spectra of hörnesite from the Gertruda adit are shown in Figure 6A. The results of the Raman analyses are reported in Table 5. Bands at 3055, 3044 and $3480 \mathrm{~cm}^{-1}$ are associated with $\mathrm{O}-\mathrm{H}$ stretching vibrations in the water. The position of these bands is very similar to those reported by Frost et al. (2003). Several broad bands at $2817-1141 \mathrm{~cm}^{-1}$ are observed. Very strong bands at 876 and $807 \mathrm{~cm}^{-1}$ are assigned to the $v_{3}$ and $v_{1}$ anti-symmetric and symmetric starching modes at arsenate groups, respectively. The band at $559 \mathrm{~cm}^{-1}$ results from the Mg-O stretching vibrations. The Raman spectrum of the low-wavenumber region includes several sharp bands. Their presence is linked to $\mathrm{V}_{4}, \mathrm{~V}_{2}$ modes and AsO bending and lattice modes (Makreski et al., 2015). The presence of hörnesite was confirmed by the PXRD method (Fig. 7A).

\section{PICROPHARMACOLITE $\mathrm{Ca}_{4} \mathrm{Mg}\left(\mathrm{HAsO}_{4}\right)_{2}\left(\mathrm{AsO}_{4}\right)_{2} \cdot 11 \mathrm{H}_{2} \mathrm{O}$}

This mineral coexists with hörnesite. It appears as acicular crystals (Fig. 5D) forming spherical aggregates on barren rock 

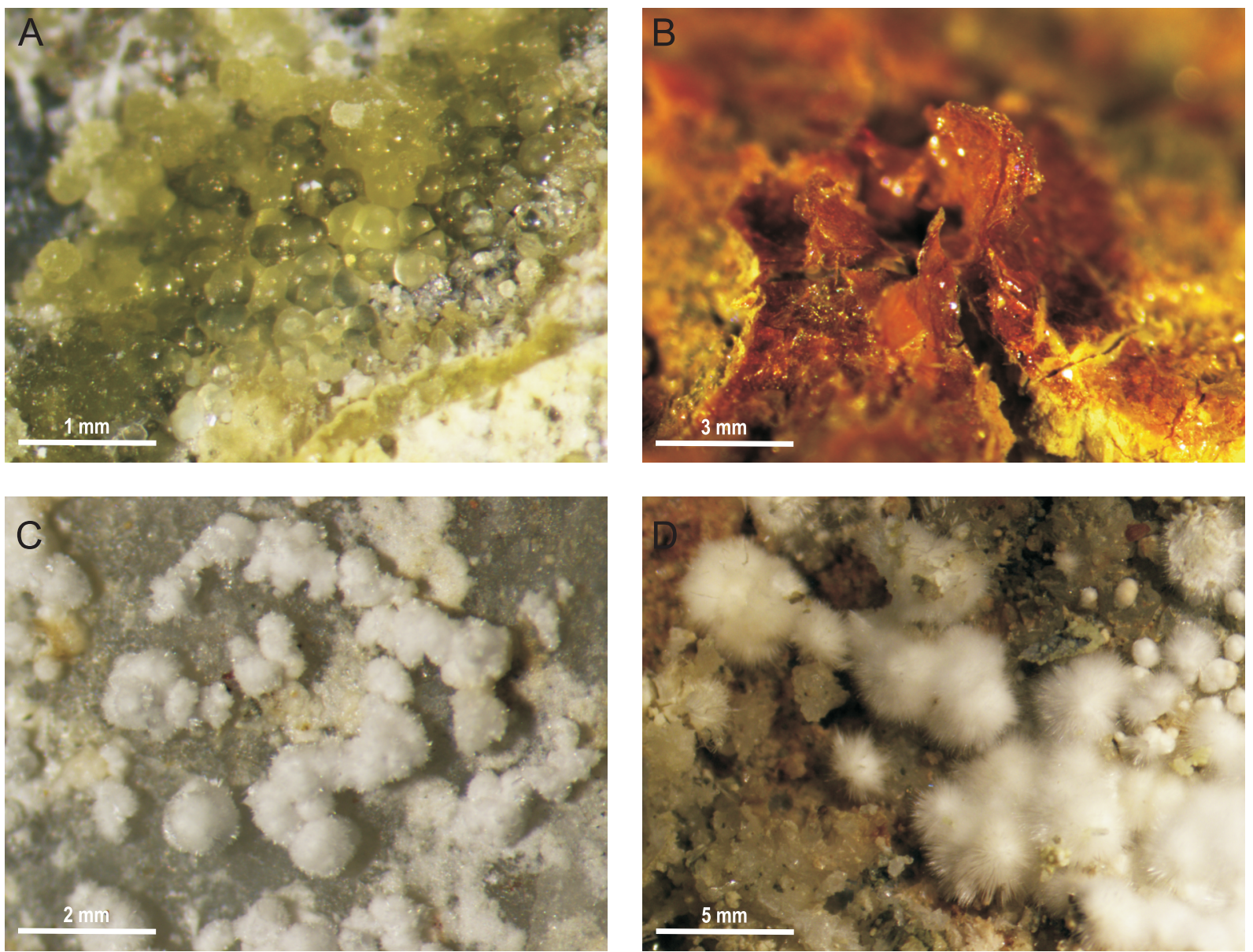

Fig. 3. Formation of secondary arsenic minerals from the Gertruda adit

A - green aggregates of scorodite II, B - accumulations of pitticite, C - white aggregates of hörnesite, D - sprays of picropharmacolite

surfaces (Fig. 3D). The investigated picropharmacolite is characterized by high chemical purity (Table 6). Only small amounts of sulphur (up to $0.03 \mathrm{apfu}$ ) were found, replacing the arsenate anion. The quantitative chemical analysis of picropharmacolite gives the following empirical formula based on 16 oxygen atoms: $\mathrm{Ca}_{4.31} \mathrm{Mg}_{0.92}\left(\mathrm{HAsO}_{4}\right)_{1.91}\left[\left(\mathrm{AsO}_{4}\right)_{1.99}\left(\mathrm{SO}_{4}\right)_{0.01}\right]_{\Sigma 2.00} \cdot 11 \mathrm{H}_{2} \mathrm{O}$. The presence of picropharmacolite was confirmed by the PXRD method (Fig. 4C).

\section{JAROSITE $\mathrm{KFe}_{3}\left(\mathrm{SO}_{4}\right)_{2}(\mathrm{OH})_{6}$}

Yellow, fine-grained, powdery aggregates (up to $0.2 \mathrm{~mm}$ in diameter) of jarosite were identified at the boundaries of the kaňkite and $\mathrm{Mg}-\mathrm{Ca}$ arsenate zones. Jarosite accumulations are composed of automorphic crystals up to $10 \mu \mathrm{m}$ in size. Results of the chemical analysis are given in Table 7. Site A is dominated by potassium, varying from 0.79 to 0.90 apfu. It is accompanied by small amounts of sodium (from 0.02 to $0.03 \mathrm{apfu}$ ) and the hydronium ion (from 0.08 to $0.19 \mathrm{apfu}$ ). In the tetrahedral site, a minor substitution of the sulphate ion (1.85 to $2.04 \mathrm{apfu}$ ) by the phosphate ion is observed (from 0.02 to $0.04 \mathrm{apfu}$ ). The calculated empirical formula of jarosite (based on 14 oxygen atoms per formula unit; the amount of $\mathrm{OH}^{-}$and $\mathrm{H}_{3} \mathrm{O}^{+}$ions was cal- culated based on the charge balance) is: $\left(\mathrm{K}_{0.83} \mathrm{H}_{3} \mathrm{O}_{0.15}^{+} \mathrm{Na}_{0.02}\right)_{\Sigma}$ ${ }_{1.00} \mathrm{Fe}_{3.01}\left[\left(\mathrm{SO}_{4}\right)_{1.97}\left(\mathrm{PO}_{4}\right)_{0.03}\right]_{\Sigma 2.00}(\mathrm{OH})_{6.00}$. This mineral was also identified by the PXRD method (Fig. 4D).

\section{GYPSUM CaSO ${ }_{4} \cdot 2 \mathrm{H}_{2} \mathrm{O}$}

This mineral occurs as small plate-like crystals, up to $20 \mu \mathrm{m}$ in length, forming spherical aggregates. They were identified at the contact of the kaňkite and Mg-Ca arsenate zones. The presence of gypsum was confirmed only by PXRD.

\section{ORPIMENT}

In the Gertruda adit, unidentified arsenic sulphide is quite common. It occurs as impregnations on wooden mining supports submerged in water. It comprises bright yellow earthy accumulations. The aggregates are formed of thin crystals up to $3 \mu \mathrm{m}$ in diameter (Fig. $5 \mathrm{E}$ ), which coexist with bacterial colonies. The chemical composition is shown in Table 8. The analysed material shows high variability of arsenic and sulphur content (57.71-64.55 wt.\% As, 21.23-31.67 wt.\% S). The presence of orpiment was confirmed by the PXRD method (Fig. 4E). 


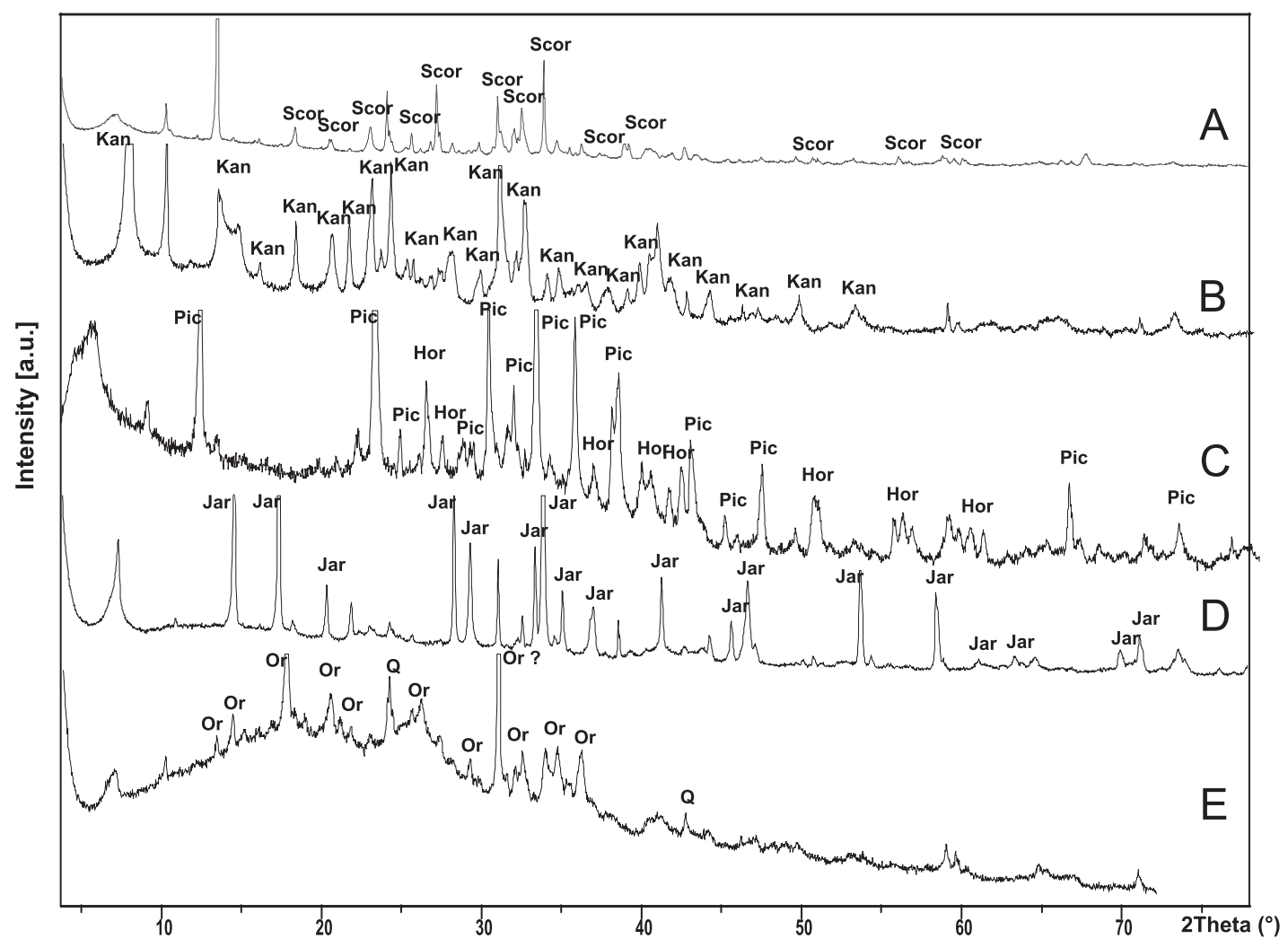

Fig. 4. PXRD patterns of secondary minerals from the Gertruda adit

A - scorodite II, B - kaňkite, C - picropharmacolite, D - jarosite, E - orpiment

\section{SUPERGENE MINERALS FROM THE WNIEBOWZIĘCIE ADIT}

ERYTHRITE $\mathrm{Co}_{3}\left(\mathrm{AsO}_{4}\right)_{2} \cdot 8 \mathrm{H}_{2} \mathrm{O}-\mathrm{HÖRNESITE} \mathrm{Mg}_{3}\left(\mathrm{AsO}_{4}\right)_{2} \cdot 8 \mathrm{H}_{2} \mathrm{O}$ - ANNABERGITE $\mathrm{Ni}_{3}\left(\mathrm{AsO}_{4}\right)_{2} \cdot 8 \mathrm{H}_{2} \mathrm{O}$ SOLID SOLUTION

In the Wniebowzięcie adit, two types of spherical aggregates of Co-Ni-Mg arsenates were found. The first type is purple and consists of plate-like crystals up to $30 \mu \mathrm{m}$ in size. Purple aggregates contain higher amount of cobalt and accumulate on the weathering surface of Co-rich löllingite (average content of cobalt is $4.5 \mathrm{wt} . \%)$. The second type of $\mathrm{Co}-\mathrm{Ni}-\mathrm{Mg}$ arsenate is light pink in colour and formed on gersdorffite aggregates associated with löllingite. The chemical composition of crystals that build the purple aggregates is shown in Table 9. Their composition is variable. The octahedral site is dominated by cobalt and magnesium, with the contents varying from 1.39 to $2.01 \mathrm{apfu}$ and from 0.61 to 1.28 apfu, respectively. These elements are accompanied by small amounts of nickel (from 0.23 to 0.34 apfu), calcium (from 0.03 to $0.07 \mathrm{apfu}$ ), and zinc (up to 0.04 apfu). The analysed crystals belong to the erythrite-hörnesite series with a slight enrichment in nickel (Fig. 8). The empirical formula of this phase was calculated based on eight oxygen atoms to be $\left(\mathrm{Co}_{1.66} \mathrm{Mg}_{1.03} \mathrm{Ni}_{0.28} \mathrm{Ca}_{0.05} \mathrm{Zn}_{0.02}\right)_{3.03}\left(\mathrm{AsO}_{4}\right)_{1.99} \cdot 8 \mathrm{H}_{2} \mathrm{O}$. In the case of the second type of aggregates, the dominant role in the cation site is played by nickel, whose content varies from 1.38 to 1.62 apfu (Table 10). In the structure, it is partially replaced by magnesium (from 0.87 to $1.01 \mathrm{apfu}$ ) and cobalt (from 0.60 to $0.70 \mathrm{apfu}$ ). They are accompanied by small amounts of calcium (from 0.09 to $0.15 \mathrm{apfu}$ ), zinc (up to $0.02 \mathrm{apfu}$ ) and iron (up to $0.01 \mathrm{apfu}$ ). The empirical formula of the analysed phase is (calculated based on eight oxygen atoms per formula unit) $\left(\mathrm{Ni}_{1.48} \mathrm{Mg}_{0.94} \mathrm{Co}_{0.66} \mathrm{Ca}_{0.12} \mathrm{Fe}_{0.01} \mathrm{Zn}_{0.01}\right)_{3.20}\left(\mathrm{AsO}_{4}\right)_{1.92} \cdot 8 \mathrm{H}_{2} \mathrm{O}$. Thus, the phase represents an $\mathrm{Mg}$ - and Co-enriched variety of annabergite (Fig. 8).

The Raman spectrum of Mg-enriched erythrite from the Wniebowzięcie adit (Fig. 6B) differs slightly from that of erythrite from Bou Azzer (Fig. 6C). The analysed sample shows the characteristic presence of three strong bands with maxima at 3456,3228 and $3068 \mathrm{~cm}^{-1}$. Compared to the Raman spectrum of pure hörnesite from the Gertruda adit, bands in this range are more visible. The bands observed at 856 and $796 \mathrm{~cm}^{-1}$ appear from the anti-symmetric and symmetric As- $\mathrm{O}_{4}$ vibrations. The positions of these bands are associated with the cation type at position A (Frost et al., 2003). In pure hörnesite, they appear at higher wave numbers (Table 5) than in pure erythrite. The position of the same bands for Mg-enriched erythrite from the Wniebowzięcie adit is intermediate and similar to the positions noted by Dumańska-Słowik et al. (2018). This shift is due to substitution between $\mathrm{Mg}^{2+}-\mathrm{Co}^{2+}$ and $\mathrm{Ni}^{2+}$ ions in the cation site.

\section{GOETHITE FEOOH AND FERRIHYDRITE $\mathrm{Fe}_{10} \mathrm{O}_{14}(\mathrm{OH})_{2}$}

These minerals coexist with each other and form small stalactites and drapes of up to several centimetres in length. In the natural humidity state, they are soft and become brittle after drying. The presence of these minerals has been confirmed only by PXRD. 

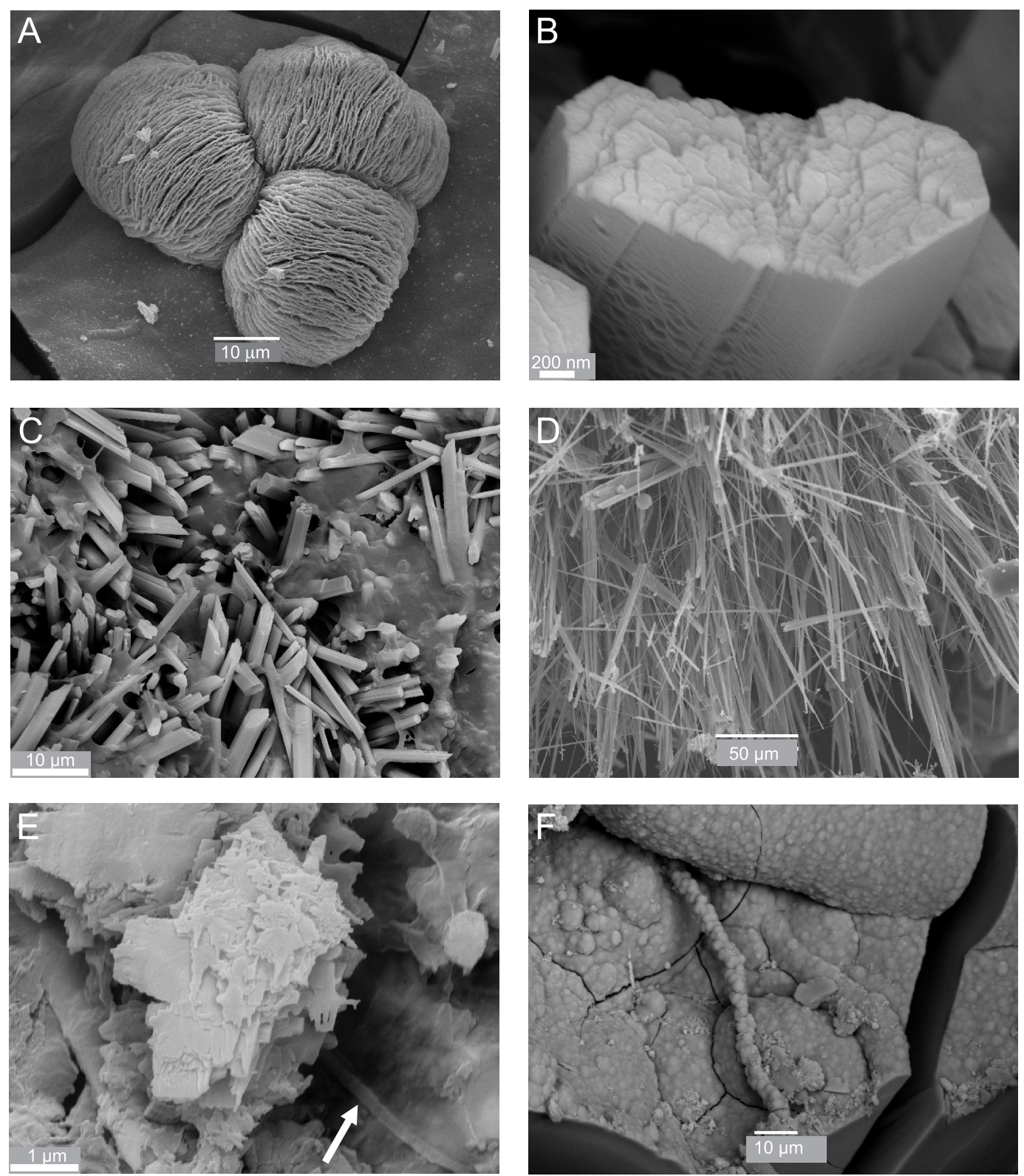

Fig. 5. SEM images of secondary arsenic minerals from the Gertruda adit

A - spherical aggregates of kaňkite on pitticite; B - mosaic termination of a hörnesite crystal; C - hörnesite crystals surrounded by a microbial mat; D - needle-like crystals of picropharmacolite; E - tabular aggregates of an unidentified arsenic sulphide from an old wooden mining construction, the arrow indicates bacterial colonies; F microbial colonies mineralised by pitticite

\section{SCHWERTMANNITE $\mathrm{Fe}_{16}\left(\mathrm{OH}, \mathrm{SO}_{4}\right)_{12-13} \mathrm{O}_{16} \cdot 10-12 \mathrm{H}_{2} \mathrm{O}$}

Schwertmannite occurs only in narrow zones (up to several centimetres in size) associated with strongly oxidized pyrite mineralisation. It forms small, up to $0.5 \mathrm{~cm}$, stalactites. At large magnifications, typical thin, needle-like crystals of this mineral are visible. The presence of this mineral has been confirmed by PXRD.

\section{DISCUSSION}

The mineral compositions of SAM parageneses are strictly dependent on the conditions of their crystallisation (Drahota and Filippi, 2009). The main factors that affect the crystallisation are the chemical composition of primary ore mineralisation and surrounding barren rocks, the humidity, $\mathrm{pH}$ and Eh, and the biological activity of microorganisms. Variability of the SAM crystallisation conditions can be observed in the oxidized ore lens exposed in the Gertruda adit. Arsenides and sulphides of iron (löllingite, arsenopyrite and pyrite) are unstable under supergene conditions. In the presence of oxygen and water, they undergo decomposition (Walker et al., 2006). This process is rapidly accelerated by $\mathrm{Fe}^{3+}$ ions - a strong oxidizing agent (Moses et al., 1987; Holmes and Crundwell, 2000). These ions are among the products of microbial activity of some bacteria strains (e.g., Schippers et al., 1996; Jones et al., 2003, Devasia and Natarajan, 2010; Vera et al., 2013; Tu et al., 2017). The presence of such bacteria was also con- 
Chemical composition [wt.\%] of kaňkite from the Gertruda adit

\begin{tabular}{|l|c|c|c|c|c|c|c|c|c|c|}
\hline $\begin{array}{c}\text { Analysis } \\
\text { number }\end{array}$ & 1 & 2 & 3 & 4 & 5 & 6 & 7 & 8 & 9 & 10 \\
\hline $\mathrm{Fe}_{2} \mathrm{O}_{3}$ & 30.16 & 31.32 & 29.06 & 29.47 & 29.16 & 29.51 & 30.36 & 30.00 & 31.99 & 30.90 \\
\hline $\mathrm{Al}_{2} \mathrm{O}_{3}$ & 1.96 & 2.87 & 1.94 & 1.63 & 2.66 & 1.58 & 1.20 & 1.04 & 1.28 & 0.90 \\
\hline $\mathrm{CaO}$ & 0.41 & 0.15 & 0.18 & 0.15 & 0.12 & 0.17 & 0.12 & 0.10 & 0.24 & 0.18 \\
\hline $\mathrm{MgO}$ & 0.35 & 0.54 & 0.35 & 0.38 & 0.47 & 0.29 & 0.24 & 0.16 & 0.17 & 0.19 \\
\hline $\mathrm{ZnO}$ & 0.08 & 0.22 & 0.34 & 0.17 & 0.06 & 0.11 & 0.00 & 0.00 & 0.00 & 0.05 \\
\hline $\mathrm{K}_{2} \mathrm{O}$ & 0.00 & 0.00 & 0.02 & 0.00 & 0.00 & 0.09 & 0.01 & 0.03 & 0.00 & 0.06 \\
\hline $\mathrm{As}_{2} \mathrm{O}_{5}$ & 42.42 & 40.53 & 45.56 & 43.59 & 42.53 & 43.26 & 46.24 & 43.82 & 44.17 & 43.03 \\
\hline $\mathrm{SO}_{3}$ & 1.10 & 1.32 & 0.82 & 1.28 & 1.36 & 0.79 & 0.87 & 0.41 & 0.34 & 0.55 \\
\hline $\mathrm{P}_{2} \mathrm{O}_{5}$ & 0.23 & 0.30 & 0.32 & 0.32 & 0.26 & 0.22 & 0.22 & 0.23 & 0.40 & 0.28 \\
\hline $\mathrm{SiO}_{2}$ & 0.15 & 0.08 & 0.02 & 0.06 & 0.01 & 0.22 & 0.08 & 0.07 & 0.11 & 0.06 \\
\hline $\mathrm{H}_{2} \mathrm{O}^{*}$ & 25.51 & 25.79 & 26.06 & 25.62 & 25.63 & 25.21 & 26.22 & 24.89 & 25.83 & 24.98 \\
\hline $\mathrm{Total}^{-102.36}$ & 103.11 & 104.67 & 102.67 & 102.25 & 101.46 & 105.57 & 100.76 & 104.53 & 101.18 \\
\hline & & & & & & & \multicolumn{2}{c|}{} \\
\hline $\mathrm{Fe}^{3+}$ & 0.93 & 0.96 & 0.88 & 0.91 & 0.90 & 0.92 & 0.91 & 0.95 & 0.98 & 0.98 \\
\hline $\mathrm{Al}^{3+}$ & 0.09 & 0.14 & 0.09 & 0.08 & 0.13 & 0.08 & 0.06 & 0.05 & 0.06 & 0.04 \\
\hline $\mathrm{Ca}^{2+}$ & 0.02 & 0.01 & 0.01 & 0.01 & 0.01 & 0.01 & 0.01 & 0.00 & 0.01 & 0.01 \\
\hline $\mathrm{Mg}^{2+}$ & 0.02 & 0.03 & 0.02 & 0.02 & 0.03 & 0.02 & 0.01 & 0.01 & 0.01 & 0.01 \\
\hline $\mathrm{Zn}^{2+}$ & 0.00 & 0.01 & 0.01 & 0.01 & 0.00 & 0.00 & 0.00 & 0.00 & 0.00 & 0.00 \\
\hline $\mathrm{K}^{+}$ & 0.00 & 0.00 & 0.00 & 0.00 & 0.00 & 0.00 & 0.00 & 0.00 & 0.00 & 0.00 \\
\hline$\Sigma \mathrm{A} \mathrm{side}^{2+}$ & 1.07 & 1.14 & 1.01 & 1.02 & 1.06 & 1.03 & 0.99 & 1.02 & 1.06 & 1.04 \\
\hline $\mathrm{AsO}_{4}^{3-}$ & 0.91 & 0.86 & 0.96 & 0.93 & 0.91 & 0.94 & 0.97 & 0.97 & 0.94 & 0.95 \\
\hline $\mathrm{SO}_{4}^{2-}$ & 0.03 & 0.04 & 0.02 & 0.04 & 0.04 & 0.02 & 0.03 & 0.01 & 0.01 & 0.02 \\
\hline $\mathrm{PO}_{4}^{3-}$ & 0.01 & 0.01 & 0.01 & 0.01 & 0.01 & 0.01 & 0.01 & 0.01 & 0.01 & 0.01 \\
\hline $\mathrm{SiO}_{4}^{4}$ & 0.01 & 0.00 & 0.00 & 0.00 & 0.00 & 0.01 & 0.00 & 0.00 & 0.00 & 0.00 \\
\hline$\Sigma \mathrm{T}_{\text {side }}$ & 0.96 & 0.92 & 1.00 & 0.99 & 0.96 & 0.98 & 1.00 & 0.99 & 0.97 & 0.98 \\
\hline $\mathrm{H}_{2} \mathrm{O}$ & 3.50 & 3.50 & 3.50 & 3.50 & 3.50 & 3.50 & 3.50 & 3.50 & 3.50 & 3.50 \\
\hline
\end{tabular}

${ }^{*} \mathrm{H}_{2} \mathrm{O}$ was calculated from the ideal content in the formula $\mathrm{H}_{2} \mathrm{O}=3.5 ; \mathrm{Mn}, \mathrm{Ni}, \mathrm{Co}$, V below detection limit

Chemical composition [wt.\%] of pitticite from the Gertruda adit

\begin{tabular}{|c|c|c|c|c|c|c|r|r|r|r|r|}
\hline $\begin{array}{c}\text { Analysis } \\
\text { number }\end{array}$ & 1 & 2 & 3 & 4 & 5 & 6 & 7 & 8 & 9 \\
\hline $\mathrm{Fe}_{2} \mathrm{O}_{3}$ & 34.14 & 33.6 & 33.94 & 33.15 & 35.03 & 34.44 & 36.92 & 34.94 & 36.43 & 36.28 \\
\hline $\mathrm{Al}_{2} \mathrm{O}_{3}$ & 0.2 & 0.22 & 0.3 & 0.28 & 0.31 & 0.31 & 0.22 & 0.24 & 0.28 & 0.25 \\
\hline $\mathrm{MgO}$ & 0.04 & 0.05 & 0.00 & 0.04 & 0.00 & 0.08 & 0.09 & 0.00 & 0.00 & 0.00 \\
\hline $\mathrm{As}_{2} \mathrm{O}_{5}$ & 37.23 & 37.67 & 36.72 & 38.34 & 39.95 & 39.88 & 38.42 & 38.38 & 38.64 & 38.11 \\
\hline $\mathrm{SO}_{3}$ & 10.67 & 10.45 & 10.57 & 10.6 & 10.84 & 10.85 & 11.36 & 10.62 & 10.96 & 11.13 \\
\hline $\mathrm{P}_{2} \mathrm{O}_{5}$ & 0.12 & 0.09 & 0.20 & 0.17 & 0.23 & 0.14 & 0.15 & 0.18 & 0.20 & 0.26 \\
\hline $\mathrm{SiO}_{2}$ & 0.02 & 0.03 & 0.03 & 0.04 & 0.06 & 0 & 0.06 & 0.01 & 0.04 & 0.05 \\
\hline $\mathrm{Total}^{*}$ & 82.42 & 82.11 & 81.76 & 82.62 & 86.42 & 85.70 & 87.22 & 84.37 & 86.55 & 86.08 \\
\hline
\end{tabular}

* Excluding water content; Mn, Ca, Ni, Co, V below detection limit 
Chemical composition [wt.\%] of hörnesite from the Gertruda adit

\begin{tabular}{|c|c|c|c|c|c|c|c|c|c|}
\hline $\begin{array}{c}\text { Analysis } \\
\text { number }\end{array}$ & 1 & 2 & 3 & 4 & 5 & 6 & 7 & 8 & 9 \\
\hline $\mathrm{MgO}$ & 27.06 & 24.94 & 25.71 & 26.70 & 26.66 & 26.38 & 25.58 & 24.35 & 24.31 \\
\hline $\mathrm{CoO}$ & 0.07 & 0.08 & 0.03 & 0.00 & 0.06 & 0.01 & 0.00 & 0.00 & 0.00 \\
\hline $\mathrm{ZnO}$ & 0.00 & 0.22 & 0.00 & 0.00 & 0.00 & 0.00 & 0.00 & 0.00 & 0.00 \\
\hline $\mathrm{CaO}$ & 1.04 & 0.98 & 0.93 & 0.79 & 0.84 & 0.69 & 0.26 & 1.21 & 0.52 \\
\hline $\mathrm{FeO}$ & 0.00 & 0.06 & 0.03 & 0.03 & 0.03 & 0.00 & 0.00 & 0.00 & 0.00 \\
\hline $\mathrm{As}_{2} \mathrm{O}_{5}$ & 43.33 & 44.55 & 43.89 & 42.44 & 43.82 & 43.80 & 44.36 & 44.74 & 45.89 \\
\hline $\mathrm{H}_{2} \mathrm{O}^{*}$ & 29.50 & 29.00 & 29.01 & 28.84 & 29.38 & 29.18 & 28.91 & 28.81 & 29.01 \\
\hline Total & 100.99 & 99.83 & 99.60 & 98.80 & 100.78 & 100.05 & 99.11 & 99.11 & 99.72 \\
\hline \multicolumn{10}{|c|}{ apfu } \\
\hline $\mathrm{Mg}^{2+}$ & 3.28 & 3.08 & 3.17 & 3.31 & 3.25 & 3.23 & 3.17 & 3.02 & 3.00 \\
\hline $\mathrm{Co}^{2+}$ & 0.00 & 0.01 & 0.00 & 0.00 & 0.00 & 0.00 & 0.00 & 0.00 & 0.00 \\
\hline $\mathrm{Ni}^{2+}$ & 0.00 & 0.00 & 0.00 & 0.00 & 0.00 & 0.00 & 0.00 & 0.00 & 0.00 \\
\hline $\mathrm{Ca}^{2+}$ & 0.09 & 0.09 & 0.08 & 0.07 & 0.07 & 0.06 & 0.02 & 0.11 & 0.05 \\
\hline $\mathrm{Fe}^{2+}$ & 0.00 & 0.00 & 0.00 & 0.00 & 0.00 & 0.00 & 0.00 & 0.00 & 0.00 \\
\hline$\Sigma$ A side & 3.38 & 3.17 & 3.26 & 3.38 & 3.32 & 3.29 & 3.19 & 3.13 & 3.04 \\
\hline $\mathrm{AsO}_{4}^{3-}$ & 1.84 & 1.93 & 1.90 & 1.85 & 1.87 & 1.88 & 1.92 & 1.95 & 1.98 \\
\hline $\mathrm{H}_{2} \mathrm{O}$ & 8 & 8 & 8 & 8 & 8 & 8 & 8 & 8 & 8 \\
\hline
\end{tabular}

${ }^{*} \mathrm{H}_{2} \mathrm{O}$ was calculated from the ideal content in the formula $\mathrm{H}_{2} \mathrm{O}=8$; Al, Mn, Ni, Co, S, V, P, Si below detection limit

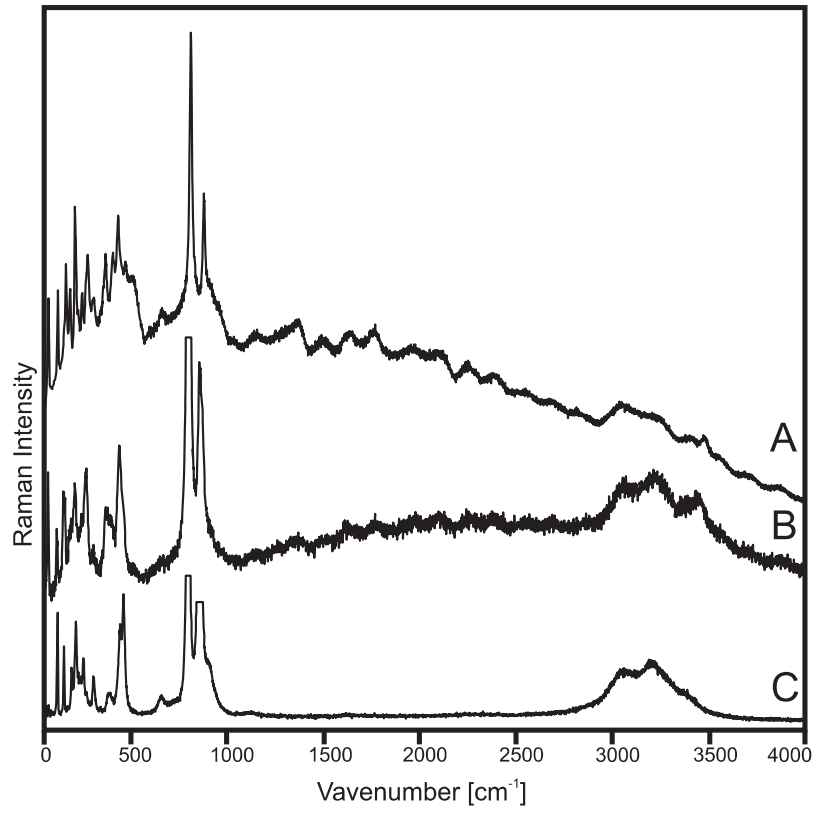

Fig. 6. Raman spectra of hörnesite from the Gertruda adit (A), erythrite-hörnesite from the Wniebowzięcie adit (B) and erythrite from Bou Azzer (Marocco) (C)

firmed in the microbial mats found in the Gertruda adit (e.g., Drawniak et al., 2010). Decomposition of primary arsenic minerals leads to the release of soluble forms of arsenic (such as arsenate and arsenite species). Arsenate ions dominate in en- vironments with high Eh potentials. Arsenite ions can be rapidly oxidized by $\mathrm{Fe}^{3+}$ ions or during microbiological processes (Nicholas et al., 2003; Drewniak et al., 2012) to the $\mathrm{AsO}_{4}^{3-}$ species (Mandl and Vyskovsky, 1994; Wiertz et al., 2006; Qin et al., 2013). In the course of iron sulphide oxidation, large amounts of sulphate ions are released into the environment, thus triggering a significant reduction in $\mathrm{pH}$.

Under low $\mathrm{pH}$ conditions and very high activity of $\mathrm{Fe}^{3+}$ and $\mathrm{AsO}_{4}^{3-}$ ions, type-l scorodite is formed. This mineral replaces arsenic ore minerals in situ. Only small relicts of primary minerals are present within the scorodite accumulations. Scorodite is stable in the relatively narrow $\mathrm{pH}$ range: from 3 to 4 (Krause and Ettel, 1989; Bluteau and Demopoulos, 2007; Paktunc and Bruggeman, 2010). As the $\mathrm{pH}$ decreases, scorodite undergoes congruent dissolution which leads to the formation of $\mathrm{Fe}^{3+}$-and $\mathrm{AsO}_{4}^{3-}$-rich pore solutions. These solutions migrate outside the type-I scorodite accumulations. Scorodite II crystallises from these solutions. Spherical aggregates of this mineral are typical of scorodite which crystallises slowly from pore solutions rich in the $\mathrm{As}(\mathrm{V})$ and $\mathrm{Fe}(\mathrm{III})$ species (Haffert and Crow, 2008). Situations of decreasing $\mathrm{pH}$, leading to dissolution of scorodite $\mathrm{I}$, are likely insignificant and short-term. The absence of zýkaite and bukovskýite confirms this observation, as these minerals are characteristic of low pH environments (2.5-3.5) (Gas`kova et al., 2008; Majzlan et al., 2012b, 2015).

The scorodite II-dominated zone contacts with pitticite accumulations. Pitticite is an amorphous hydrated sulphoarsenate of iron. It is a typical product of weathering of primary arsenic minerals which takes place in acidic environments (e.g., Kocourková et al., 2011b; Parviainen et al., 2012). The presence of highly mineralised bacterial colonies within the pitticite accumulations (Fig. 
Position and assignment of the bands $\left[\mathrm{cm}^{-1}\right]$ in the Raman spectra of Mg and Co arsenates from Złoty Stok, and comparison with literature data

\begin{tabular}{|c|c|c|c|c|c|c|}
\hline $\begin{array}{l}\text { Hörnesite } \\
\text { from the } \\
\text { Gertruda adit }\end{array}$ & $\begin{array}{c}\text { Hörnesite } \\
\text { (Frost et al., 2003) }\end{array}$ & $\begin{array}{c}\text { Hörnesite } \\
\text { (Makreski et al., 2015) }\end{array}$ & $\begin{array}{l}\text { Erythrite from the } \\
\text { Wniebowzięcie adit }\end{array}$ & $\begin{array}{l}\text { Erythrite from } \\
\text { Bou Azzer } \\
\text { (this work) }\end{array}$ & $\begin{array}{c}\text { Erythrite } \\
\text { (Frost et al., 2003) }\end{array}$ & $\begin{array}{l}\text { Band } \\
\text { assignment }\end{array}$ \\
\hline 68 & & & 68 & 70 & & \\
\hline \multirow[t]{3}{*}{118} & 117 & & 113 & 113 & & Lattice modes \\
\hline & & 138 & & & & Lattice modes \\
\hline & & & 149 & 149 & & Lattice modes \\
\hline 160 & 159 & 158 & & & 162 & Lattice modes \\
\hline 181 & 180 & 180 & & 189 & 188 & Lattice modes \\
\hline \multirow[t]{2}{*}{205} & 206 & 205 & 206 & & & Lattice modes \\
\hline & & & & 211 & 209 & Lattice modes \\
\hline \multirow[t]{2}{*}{222} & 218 & & & & 223 & \begin{tabular}{|l|} 
Lattice modes \\
\end{tabular} \\
\hline & & & & & 234 & \\
\hline \multirow[t]{3}{*}{241} & 243 & 242 & 240 & 245 & & Lattice modes \\
\hline & & & & 250 & 249 & Lattice modes \\
\hline & 262 & 262 & 263 & 262 & 263 & Lattice modes \\
\hline 273 & 273 & 271 & & & & Lattice modes \\
\hline 304 & 303 & 301 & 303 & 302 & 301 & $\mathrm{v}_{2}\left(\mathrm{AsO}_{4}\right)$ \\
\hline \multirow[t]{4}{*}{365} & 363 & 365 & & & & $\mathrm{v}_{2}\left(\mathrm{AsO}_{4}\right)$ \\
\hline & & & 377 & & 378 & $\mathrm{v}_{2}\left(\mathrm{AsO}_{4}\right)$ \\
\hline & & & 389 & 383 & & $\mathrm{~V}_{2}\left(\mathrm{AsO}_{4}\right)$ \\
\hline & & & & & 391 & \\
\hline 404 & 403 & 403 & & & & $\mathrm{v}_{4}\left(\mathrm{AsO}_{4}\right)$ \\
\hline \multirow[t]{4}{*}{430} & 429 & 430 & & & & $\mathrm{v}_{4}\left(\mathrm{AsO}_{4}\right)$ \\
\hline & & & 437 & 442 & 439 & $\mathrm{~V}_{4}\left(\mathrm{AsO}_{4}\right)$ \\
\hline & 446 & & & & & \\
\hline & & & & 459 & 457 & $\mathrm{v}_{4}\left(\mathrm{AsO}_{4}\right)$ \\
\hline 467 & 467 & 468 & & & 467 & $\mathrm{v}_{4}\left(\mathrm{AsO}_{4}\right)$ \\
\hline \multicolumn{7}{|l|}{508} \\
\hline \multirow[t]{3}{*}{657} & 660 & & & 651 & 652 & \\
\hline & & & & & 727 & \\
\hline & & & 796 & 793 & 792 & $\mathrm{v}_{1}\left(\mathrm{AsO}_{4}\right)$ \\
\hline \multirow[t]{2}{*}{807} & 807 & 808 & & & & $\mathrm{v}_{1}\left(\mathrm{AsO}_{4}\right)$ \\
\hline & & & 856 & 852 & 852 & $\mathrm{v}_{3}\left(\mathrm{AsO}_{4}\right)$ \\
\hline \multirow[t]{2}{*}{875} & 875 & 875 & & & & $\mathrm{v}_{3}\left(\mathrm{AsO}_{4}\right)$ \\
\hline & 907 & & & 906 & 902 & \\
\hline $2817-1141$ & & & $\begin{array}{l}2280-1140 \text { poor } \\
\text { band intensity }\end{array}$ & & & \\
\hline \multirow[t]{4}{*}{3055} & 3030 & & 3068 & 3065 & 3052 & $\mathrm{OH}$ stretching \\
\hline & 3166 & & & & & \\
\hline & & & 3228 & 3202 & 3200 & $\mathrm{OH}$ stretching \\
\hline & & & & & 3337 & \\
\hline \multirow[t]{2}{*}{3404} & & & & & & $\mathrm{OH}$ stretching \\
\hline & & & 3456 & & & $\mathrm{OH}$ stretching \\
\hline 3480 & 3479 & & & & & $\mathrm{OH}$ stretching \\
\hline
\end{tabular}

$5 \mathrm{~F}$ ) indicates the involvement of microorganisms in the precipitation of this phase. In relation to crystalline iron arsenates, the amorphous hydrated sulphoarsenate of $\mathrm{Fe}$ is unstable. Maturation of pitticite leads to the formation of crystalline Fe arsenates (Paktunc et al., 2008). On the other hand, pitticite can dissolve due to a slight decrease in arsenate or sulphate ions concentration (Chukhlantsev, 1956; Robins, 1987; Langmuir et al., 2006). For this reason, it may be a precursor to the coexisting kaňkite. Kaňkite crystallises primarily in post-mining or underground mining excavations (Majzlan et al., 2014). No direct crystallisation of kaňkite has been observed on the weathering surfaces of ar- senic ore minerals. This observation may indicate that crystallisation of kaňkite is related to migration of arsenate-rich porous solutions. Furthermore, kaňkite is found only in very highly humid environments (Kato et al., 1984; Haffert et al., 2010; Majzlan et al., 2014). Kaňkite from the Gertruda adit is a younger phase in relation to scorodite and pitticite (Fig. 5A). This confirms the observations of other authors who related crystallisation of this mineral to dissolution of previously formed secondary iron arsenates (Haffert et al., 2010; Kocourková et al., 2011a). Kaňkite coexists with a small amount of jarosite, which is an indicator of low $\mathrm{pH}$. Experimental data show that kaňkite is metastable with 


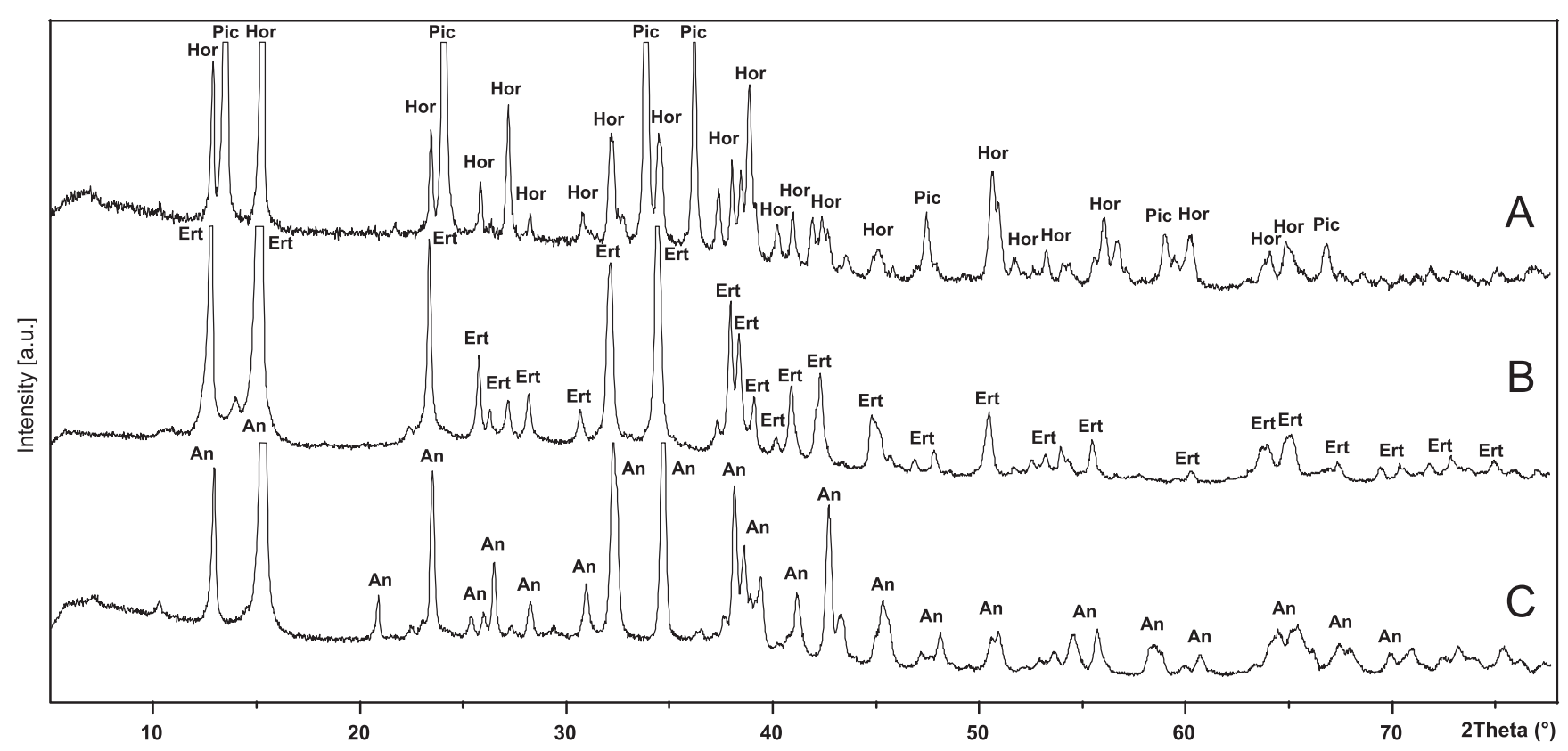

Fig. 7. PXRD patterns of Mg, Co, Ni arsenates from Złoty Stok

A - hörnesite (from the Gertruda adit), B - erythrite (from the Wniebowzięcie adit), C - annabergite (from the Wniebowzięcie adit)

Table 6

Chemical composition [wt.\%] of picropharmacolite from the Gertruda adit

\begin{tabular}{|c|c|c|c|c|c|c|c|c|c|c|}
\hline $\begin{array}{l}\text { Analysis } \\
\text { number }\end{array}$ & 1 & 2 & 3 & 4 & 5 & 6 & 7 & 8 & 9 & 10 \\
\hline $\mathrm{CaO}$ & 24.28 & 28.03 & 25.10 & 25.16 & 25.13 & 25.29 & 25.97 & 25.76 & 27.20 & 27.71 \\
\hline $\mathrm{MgO}$ & 3.89 & 3.51 & 4.12 & 4.09 & 3.68 & 3.87 & 4.16 & 4.16 & 4.11 & 4.29 \\
\hline $\mathrm{As}_{2} \mathrm{O}_{5}$ & 47.37 & 49.56 & 47.89 & 46.62 & 45.00 & 46.52 & 50.10 & 50.51 & 48.83 & 48.90 \\
\hline $\mathrm{SO}_{3}$ & 0.12 & 0.00 & 0.14 & 0.11 & 0.20 & 0.28 & 0.00 & 0.20 & 0.00 & 0.13 \\
\hline $\mathrm{H}_{2} \mathrm{O}^{*}$ & 22.56 & 23.80 & 23.26 & 22.68 & 22.19 & 22.69 & 23.70 & 23.97 & 23.62 & 23.85 \\
\hline Total & 98.22 & 104.89 & 100.52 & 98.65 & 96.21 & 98.65 & 103.93 & 104.59 & 103.75 & 104.87 \\
\hline \multicolumn{11}{|c|}{ apfu } \\
\hline $\mathrm{Ca}^{2+}$ & 4.15 & 4.54 & 4.16 & 4.28 & 4.37 & 4.30 & 4.22 & 4.14 & 4.44 & 4.48 \\
\hline $\mathrm{Mg}^{2+}$ & 0.93 & 0.79 & 0.95 & 0.97 & 0.89 & 0.91 & 0.94 & 0.93 & 0.93 & 0.97 \\
\hline$\Sigma \mathrm{A}$ side & 5.07 & 5.33 & 5.11 & 5.24 & 5.26 & 5.21 & 5.17 & 5.07 & 5.37 & 5.44 \\
\hline $\mathrm{AsO}_{4}^{3-}$ & 1.99 & 2.00 & 1.98 & 1.99 & 1.98 & 1.97 & 2.00 & 1.98 & 2.00 & 1.98 \\
\hline $\mathrm{SO}_{4}^{2-}$ & 0.01 & 0.00 & 0.02 & 0.01 & 0.02 & 0.03 & 0.00 & 0.02 & 0.00 & 0.02 \\
\hline$\left(\mathrm{HAsO}_{4}\right)^{2-}$ & 1.97 & 1.92 & 1.89 & 1.88 & 1.84 & 1.89 & 1.98 & 1.99 & 1.89 & 1.87 \\
\hline$\Sigma T$ side & 3.97 & 3.92 & 3.89 & 3.88 & 3.84 & 3.89 & 3.98 & 3.99 & 3.89 & 3.87 \\
\hline $\mathrm{H}_{2} \mathrm{O}$ & 11.00 & 11.00 & 11.00 & 11.00 & 11.00 & 11.00 & 11.00 & 11.00 & 11.00 & 11.00 \\
\hline
\end{tabular}

${ }^{*} \mathrm{H}_{2} \mathrm{O}$ was calculated from the ideal content in the formula $\mathrm{H}_{2} \mathrm{O}=11$ and charge balance; $\mathrm{Fe}, \mathrm{Al}, \mathrm{Mn}, \mathrm{Ni}$, Co below detection limit

respect to liquid water or water vapour (Majzlan et al., 2012a). Decomposition of this mineral may be the source of the $\mathrm{AsO}_{4}^{3-}$ ions for other secondary arsenates to form. The formation of Hörnesite and picropharmacolite is associated with the reaction of acidic arsenic-rich pore solutions with carbonates from barren rocks. These rocks contain variable amounts of calcite and dolo- mite, which are the source of $\mathrm{Mg}^{2+}$ and $\mathrm{Ca}^{2+}$ ions. The interaction of carbonates with acid pore solutions causes a rapid increase in $\mathrm{pH}$. Based on observations of crystallisation conditions of $\mathrm{Mg}-\mathrm{Ca}$ arsenates in southern France (Juillot et al., 1999) it can be assumed that the corresponding process in the Gertrude adit takes place under neutral or weakly alkaline $\mathrm{pH}$ conditions. Sulphate 
Chemical composition [wt.\%] of jarosite from the Gertruda adit

\begin{tabular}{|c|c|c|c|c|c|c|}
\hline $\begin{array}{c}\text { Analysis } \\
\text { number }\end{array}$ & 1 & 2 & 3 & 4 & 5 & 6 \\
\hline $\mathrm{K}_{2} \mathrm{O}$ & 6.63 & 7.20 & 6.95 & 7.12 & 7.83 & 7.61 \\
\hline $\mathrm{Na}_{2} \mathrm{O}$ & 0.16 & 0.16 & 0.13 & 0.09 & 0.12 & 0.15 \\
\hline $\mathrm{Fe}_{2} \mathrm{O}_{3}$ & 43.54 & 44.01 & 43.12 & 46.54 & 45.20 & 44.40 \\
\hline $\mathrm{SO}_{3}$ & 24.92 & 31.14 & 30.57 & 30.04 & 28.85 & 30.09 \\
\hline $\mathrm{P}_{2} \mathrm{O}_{5}$ & 0.37 & 0.53 & 0.40 & 0.33 & 0.35 & 0.34 \\
\hline $\mathrm{H}_{2} \mathrm{O}^{*}$ & 9.30 & 10.66 & 10.45 & 10.67 & 10.14 & 10.35 \\
\hline Total & 84.92 & 93.70 & 91.62 & 94.79 & 92.49 & 92.94 \\
\hline \multicolumn{7}{|c|}{ apfu } \\
\hline $\mathrm{K}^{+}$ & 0.84 & 0.80 & 0.79 & 0.79 & 0.90 & 0.86 \\
\hline $\mathrm{Na}^{+}$ & 0.03 & 0.03 & 0.02 & 0.02 & 0.02 & 0.03 \\
\hline $\mathrm{H}_{3} \mathrm{O}^{+}$ & 0.13 & 0.18 & 0.19 & 0.19 & 0.08 & 0.11 \\
\hline$\Sigma$ A side & 1.00 & 1.00 & 1.00 & 1.00 & 1.00 & 1.00 \\
\hline $\mathrm{Fe}^{3+}$ & 3.24 & 2.88 & 2.88 & 3.05 & 3.06 & 2.96 \\
\hline $\mathrm{SO}_{4}^{2-}$ & 1.85 & 2.03 & 2.04 & 1.96 & 1.95 & 2.00 \\
\hline $\mathrm{PO}_{4}^{3-}$ & 0.03 & 0.04 & 0.03 & 0.02 & 0.03 & 0.03 \\
\hline$\Sigma T$ side & 1.88 & 2.07 & 2.07 & 1.98 & 1.97 & 2.02 \\
\hline $\mathrm{OH}^{-}$ & 6.93 & 5.45 & 5.48 & 6.14 & 6.20 & 5.80 \\
\hline
\end{tabular}

${ }^{*} \mathrm{H}_{2} \mathrm{O}$ content was calculated based on charge balance; $\mathrm{Al}, \mathrm{Mn}$, As below detection limit

Chemical composition [wt.\%] of orpiment from the Gertruda adit

\begin{tabular}{|l|c|c|c|c|c|c|c|c|c|}
\hline $\begin{array}{c}\text { Analysis } \\
\text { number }\end{array}$ & 1 & 2 & 3 & 4 & 5 & 6 & 7 & 8 & 9 \\
\hline S & 22.08 & 21.23 & 31.67 & 23.07 & 25.85 & 27.78 & 25.63 & 23.44 & 20.72 \\
\hline As & 59.87 & 57.71 & 64.55 & 56.41 & 62.44 & 60.44 & 63.54 & 59.53 & 49.73 \\
\hline Total & 81.95 & 78.94 & 96.22 & 79.48 & 88.29 & 88.22 & 89.17 & 82.97 & 70.45 \\
\hline
\end{tabular}

ions that accompany arsenate ions are bound in gypsum crystals that co-exist with hörnesite and picropharmacolite. A similar process of the formation of $\mathrm{Mg}-\mathrm{Ca}$ arsenates has been described from abandoned mine galleries in Jachymov, Czech Republic (Ondruš et al., 1997a, b). Crystallisation of hörnesite (and the accompanying picropharmacolite) under neutral or alkalescent $\mathrm{pH}$ conditions is also confirmed by the existence of hörnesite in soils with high arsenic content (Voigt et al., 1996; Foster et al., 1997). It is also worth noting that hörnesite aggregates are often associated with colonies of microorganisms (Fig. 5C). Their role in the formation of this mineral has not been fully established. There is a possibility that $\mathrm{As}$ and $\mathrm{Mg}^{2+}$ concentrations within such colonies somehow increase to the value at which crystallisation of hörnesite is possible.

Supergene Co-Mg-Ni arsenates of the erythrite-hörnesite-annabergite solid solution occur beyond the above-described ore lenses at the Wniebowzięcie adit. Their crystallisation is related to the decomposition of arsenides containing cobalt and nickel. Weathering of these minerals does not cause a significant reduction in $\mathrm{pH}$. This is because the decomposition of
Co-Ni arsenides does not release sulphuric acid but only poorly dissociated arsenic acid. The arsenic acid reacts with the released $\mathrm{Co}^{2+}$ and $\mathrm{Ni}^{2+}$ ions, which in turn leads to the appearance of secondary minerals directly at the surface of the ores. $\mathrm{Mg}^{2+}$ ions are supplied to the system from dolomite-containing barren rocks. The formation of the erythrite-hörnesite-annabergite solid solution is very similar to the mechanism described by Markl et al. (2014) to occur in supergene zones of various German polymetallic mines. According to data obtained by Langmuir et al. (1999) and Mahoney et al. (2007) these arsenates crystalised from slightly acidic media $(\mathrm{pH} \sim 5-6)$. These data were confirmed by Yuan et al. (2005), who proved that the solubility of annabergite decreases with increasing $\mathrm{pH}$ (minimal at $\mathrm{pH}=9$ ). The same relationship was confirmed for erythrite (Zhu et al., 2013). In several parts of the Wniebowzięcie adit, schwertmannite was found. Its occurrence is limited to small zones containing disseminated pyrite mineralisation (without arsenopyrite and löllingite) which appears inside blastomyllonites. Moreover, some SAM were found with schwertmannite. This mineral is an indicator of acidic environmental conditions 
Chemical composition [wt.\%] of erythrite from the Wniebowzięcie adit

\begin{tabular}{|c|c|c|c|c|c|c|c|c|c|c|}
\hline $\begin{array}{c}\text { Analysis } \\
\text { number }\end{array}$ & 1 & 2 & 3 & 4 & 5 & 6 & 7 & 8 & 9 & 10 \\
\hline $\mathrm{CoO}$ & 25.93 & 25.30 & 24.35 & 21.71 & 21.33 & 21.14 & 20.30 & 19.10 & 19.03 & 19.18 \\
\hline $\mathrm{MgO}$ & 4.26 & 4.77 & 5.02 & 8.47 & 7.15 & 7.22 & 9.09 & 8.97 & 9.11 & 9.43 \\
\hline $\mathrm{NiO}$ & 3.91 & 3.47 & 3.54 & 3.53 & 3.59 & 4.47 & 3.50 & 3.75 & 3.06 & 3.43 \\
\hline $\mathrm{ZnO}$ & 0.31 & 0.40 & 0.17 & 0.00 & 0.18 & 0.38 & 0.16 & 0.14 & 0.00 & 0.63 \\
\hline $\mathrm{CaO}$ & 0.47 & 0.28 & 0.30 & 0.44 & 0.59 & 0.40 & 0.38 & 0.44 & 0.59 & 0.68 \\
\hline $\mathrm{FeO}$ & 0.00 & 0.00 & 0.00 & 0.00 & 0.00 & 0.00 & 0.00 & 0.00 & 0.00 & 0.00 \\
\hline $\mathrm{As}_{2} \mathrm{O}_{5}$ & 39.51 & 39.14 & 39.80 & 39.61 & 39.99 & 39.79 & 40.68 & 40.27 & 40.32 & 42.02 \\
\hline $\mathrm{H}_{2} \mathrm{O}^{*}$ & 26.40 & 26.19 & 26.75 & 26.52 & 26.78 & 26.43 & 26.92 & 26.61 & 26.62 & 26.48 \\
\hline Total & 100.78 & 99.55 & 99.93 & 100.27 & 99.61 & 99.82 & 101.02 & 99.28 & 98.73 & 101.85 \\
\hline \multicolumn{11}{|c|}{ apfu } \\
\hline $\mathrm{Co}^{2+}$ & 2.01 & 1.98 & 1.90 & 1.64 & 1.63 & 1.61 & 1.51 & 1.44 & 1.44 & 1.39 \\
\hline $\mathrm{Mg}^{2+}$ & 0.61 & 0.69 & 0.73 & 1.19 & 1.02 & 1.02 & 1.26 & 1.26 & 1.28 & 1.27 \\
\hline $\mathrm{Ni}^{2+}$ & 0.30 & 0.27 & 0.28 & 0.27 & 0.28 & 0.34 & 0.26 & 0.28 & 0.23 & 0.25 \\
\hline $\mathrm{Zn}^{2+}$ & 0.02 & 0.03 & 0.01 & 0.00 & 0.01 & 0.03 & 0.01 & 0.01 & 0.00 & 0.04 \\
\hline $\mathrm{Ca}^{2+}$ & 0.05 & 0.03 & 0.03 & 0.04 & 0.06 & 0.04 & 0.04 & 0.04 & 0.06 & 0.07 \\
\hline$\Sigma \mathrm{A}$ side & 3.00 & 3.01 & 2.95 & 3.13 & 3.00 & 3.05 & 3.07 & 3.04 & 3.02 & 3.02 \\
\hline $\mathrm{AsO}_{4}^{3-}$ & 2.00 & 2.00 & 2.02 & 1.95 & 2.00 & 1.98 & 1.97 & 1.98 & 1.99 & 1.99 \\
\hline $\mathrm{H}_{2} \mathrm{O}$ & 8.00 & 8.00 & 8.00 & 8.00 & 8.00 & 8.00 & 8.00 & 8.00 & 8.00 & 8.00 \\
\hline
\end{tabular}

${ }^{*} \mathrm{H}_{2} \mathrm{O}$ was calculated from the ideal content in the formula $\mathrm{H}_{2} \mathrm{O}=8$; Mn, S, P, V, Si below detection limit

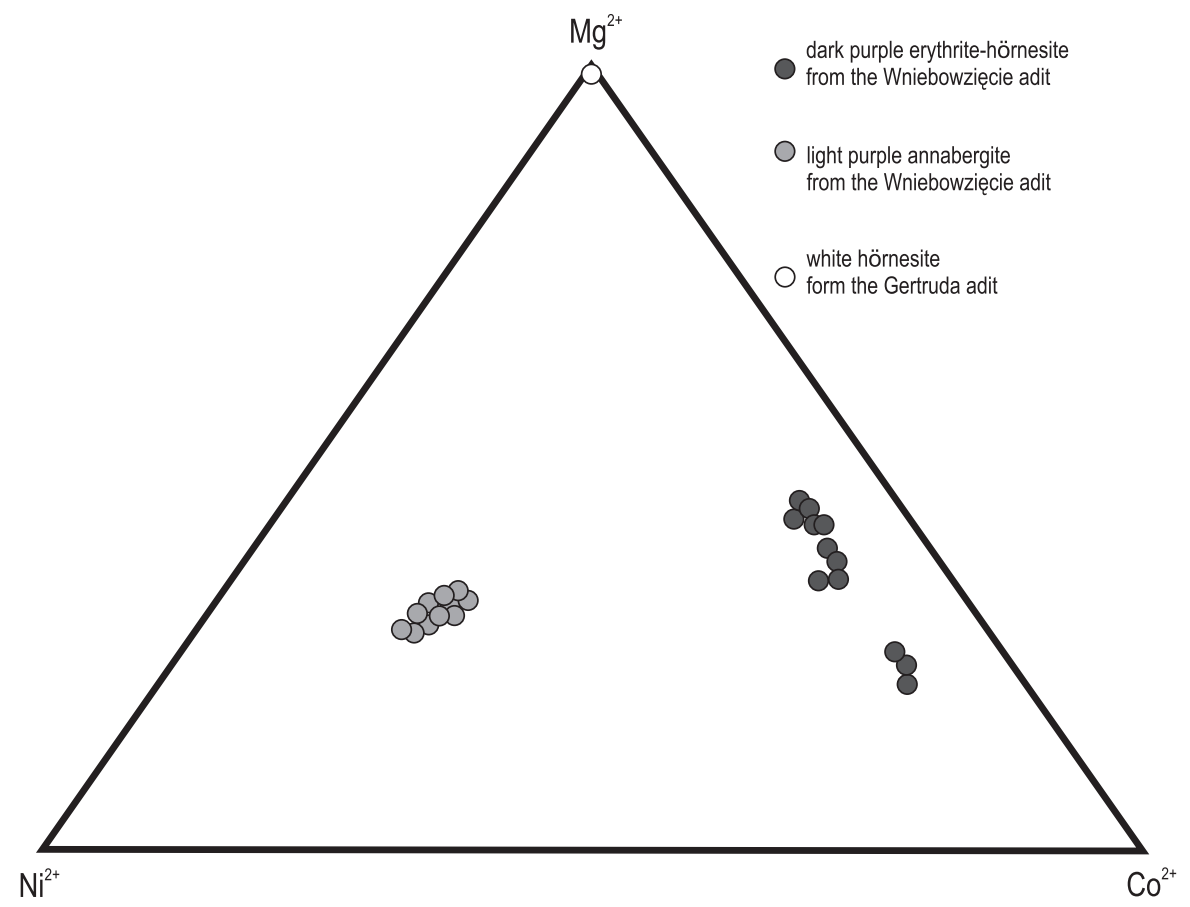

Fig. 8. Ternary plot of the chemical composition of Mg-Co-Ni arsenates from the Gertruda and Wniebowzięcie adits (in atoms per formula units) 
Chemical composition [wt.\%] of annabergite from the Wniebowzięcie adit

\begin{tabular}{|c|c|c|c|c|c|c|c|c|c|}
\hline $\begin{array}{c}\text { Analysis } \\
\text { number }\end{array}$ & 1 & 2 & 3 & 4 & 5 & 6 & 7 & 8 & 9 \\
\hline $\mathrm{NiO}$ & 18.51 & 18.80 & 19.96 & 19.92 & 19.58 & 19.30 & 21.06 & 19.25 & 18.19 \\
\hline $\mathrm{CoO}$ & 8.97 & 9.01 & 7.96 & 8.55 & 8.47 & 9.20 & 7.76 & 8.70 & 9.23 \\
\hline $\mathrm{MgO}$ & 7.07 & 7.27 & 6.12 & 7.11 & 6.11 & 6.52 & 6.11 & 6.67 & 6.95 \\
\hline $\mathrm{ZnO}$ & 0.22 & 0.04 & 0.00 & 0.00 & 0.17 & 0.00 & 0.00 & 0.00 & 0.30 \\
\hline $\mathrm{CaO}$ & 1.38 & 1.53 & 1.02 & 1.15 & 0.85 & 1.29 & 0.91 & 1.21 & 1.38 \\
\hline $\mathrm{FeO}$ & 0.07 & 0.00 & 0.16 & 0.01 & 0.07 & 0.14 & 0.08 & 0.01 & 0.04 \\
\hline $\mathrm{As}_{2} \mathrm{O}_{5}$ & 39.23 & 38.65 & 38.56 & 38.50 & 39.16 & 40.05 & 38.42 & 37.83 & 38.64 \\
\hline $\mathrm{H}_{2} \mathrm{O}^{*}$ & 25.70 & 25.67 & 24.99 & 25.53 & 25.18 & 25.93 & 25.05 & 24.93 & 25.38 \\
\hline Total & 101.14 & 100.96 & 98.76 & 100.75 & 99.59 & 102.43 & 99.39 & 98.60 & 100.11 \\
\hline \multicolumn{10}{|c|}{ apfu } \\
\hline $\mathrm{Ni}^{2+}$ & 1.39 & 1.41 & 1.54 & 1.51 & 1.50 & 1.44 & 1.62 & 1.49 & 1.38 \\
\hline $\mathrm{Co}^{2+}$ & 0.67 & 0.68 & 0.61 & 0.64 & 0.65 & 0.68 & 0.60 & 0.67 & 0.70 \\
\hline $\mathrm{Mg}^{2+}$ & 0.98 & 1.01 & 0.88 & 1.00 & 0.87 & 0.90 & 0.87 & 0.96 & 0.98 \\
\hline $\mathrm{Zn}^{2+}$ & 0.01 & 0.00 & 0.00 & 0.00 & 0.01 & 0.00 & 0.00 & 0.00 & 0.02 \\
\hline $\mathrm{Ca}^{2+}$ & 0.14 & 0.15 & 0.10 & 0.12 & 0.09 & 0.13 & 0.09 & 0.12 & 0.14 \\
\hline $\mathrm{Fe}^{2+}$ & 0.01 & 0.00 & 0.01 & 0.00 & 0.01 & 0.01 & 0.01 & 0.00 & 0.00 \\
\hline$\Sigma$ A side & 3.20 & 3.26 & 3.15 & 3.26 & 3.12 & 3.16 & 3.19 & 3.24 & 3.23 \\
\hline $\mathrm{AsO}_{4}^{3-}$ & 1.91 & 1.89 & 1.94 & 1.89 & 1.95 & 1.94 & 1.92 & 1.90 & 1.91 \\
\hline $\mathrm{H}_{2} \mathrm{O}$ & 8 & 8 & 8 & 8 & 8 & 8 & 8 & 8 & 8 \\
\hline
\end{tabular}

${ }^{*} \mathrm{H}_{2} \mathrm{O}$ was calculated from the ideal content in the formula $\mathrm{H}_{2} \mathrm{O}=8$; Mn, S, P, V, Si below detection limit

$(\mathrm{pH}=3-4)$ and high activity of sulphate ions (Parafiniuk and Siuda, 2006). Schwertmannite is a metastable mineral, susceptible to environmental changes (Yu et al., 2002). In humid periods of the year, an increased flow of meteoric waters of neutral $\mathrm{pH}$ results in transformation of schwertmannite into ferrihydrite and goethite. This causes the schwertmannite-bound sulphate ions to be released into mine waters.

Arsenate and sulphate ions of mine waters can be reduced under anaerobic conditions. Bacteria play a key role in this process (Nicholas et al., 2003). Arsenic sulphides of various As:S ratios stand for the products of such bacterially-driven reduction (e.g., Newman et al., 1997; Ledbetter et al., 2007; Battaglia-Brunet et al., 2012; Rodriguez-Freire et al., 2014, 2016). Different strains of bacteria, which reduce $\mathrm{As}(\mathrm{V})$ to As(III) were identified in the microbial mats from the Gertruda adit (Drewniak et al., 2010, 2012; Tomczyk-Żak et al., 2013, Cłapała et al., 2016). In this process, the arsenic and sulphate ions are electron acceptors, whereas organic matter from the old wooden mining construction acts as an electron donor. Then, arsenic sulphide is formed and precipitates only in the interstices of wood impregnated with the bacterial colonies, which clearly indicates that this process is related to organic matter and microbial activity.

\section{CONCLUSIONS}

Secondary arsenic minerals (SAM) from the As-Au mine at Złoty Stok are a unique assemblage of supergene minerals in Poland. These minerals record changes in environmental conditions in the abandoned mine galleries. Under oxidizing conditions, the dominant solid phases are arsenates. Iron arsenates occur only in areas of low $\mathrm{pH}$ and high activity of $\mathrm{Fe}^{3+}$ ions. Such zones develop when the primary arsenic minerals and pyrite are weathered. The first mineral to crystallise is scorodite I. This mineral is partly dissolved and recrystallized as scorodite II. Arsenate and ferric ions released in this process are bound up in pitticite and kaňkite. The barren rocks, which surround the weathering ore minerals, contain calcite and dolomite that are a source of $\mathrm{Ca}^{2+}$ and $\mathrm{Mg}^{2+}$ species.

Hörnesite and picropharmacolite are the products of the reaction between $\mathrm{Ca}^{2+}, \mathrm{Mg}^{2+}$ and $\mathrm{AsO}_{4}{ }^{3-}$ ions. These minerals crystallise under neutral or slightly alkaline $\mathrm{pH}$ conditions, with increasing $\mathrm{pH}$ values resulting from carbonates dissolution. Arsenates of the erythrite-annabergite-hörnesite solid solution are produced by decomposition of primary Co-Ni arsenides. This process does not cause a significant $\mathrm{pH}$ reduction. For this reason, these minerals crystallise under slightly acidic $\mathrm{pH}$ conditions. Under anoxic conditions arsenate and sulphate ions present in the mine waters undergo bacterial reduction. The arsenic sulphides form in this way. Microorganisms take part in the formation of secondary arsenic minerals. They accelerate both reactions: the oxidation of reduced arsenic forms and the reduction of arsenate ions. The abandoned adits of the Złoty Stok As-Au mine are the first documented place in Poland where the SAM record the full circulation of arsenic in a supergene environment.

Acknowledgements. The study was financed by an IGMiP project. Authors would like to thank A. Borkowski, T. Segit, M. Kałaska and M. Syczewski for their help in the field work. Special thanks go to E. Szumska for enabling our research in the Złoty Stok abandoned gold mine. Authors also would like to thank R. Macdonald for correcting the English version of this article. 


\section{REFERENCES}

Battaglia-Brunet, F., Crouzet, C., Burnol, A., Coulon, S., Morin, D., Joulian, C., 2012. Precipitation of arsenic from acidic water in a fixed-film bioreactor. Water Research, 46: 3923-3933.

Bluteau, M.C., Demopoulos, G.P., 2007. The incongruent dissolution of scorodite - solubility, kinetics and mechanism. Hydrometallurgy, 87: 163-177.

Budzyńska, H., 1971. Mineralogy of Złoty Stok arsenic deposit (Polish with English summary). Archiwum Mineralogiczne, 29: 30-74.

Chukhlantsev, V.G., 1956. The solubility products of a number of arsenates (in Russian). Journal of Analytical Chemistry, 11: 529-535.

Cłapała, T., Narożna, D., Siuda, R., Borkowski, A., Selwet, M., Mądrzak, C.J., Koźlecka, E., 2016. Bacterial Communities from the arsenic mine in Złoty Stok, Sudety Mountains, Poland. Polish Journal of Microbiology, 66: 375-381.

Cwojdziński, S., 1974. Szczegółowa Mapa Geologiczna Sudetów w skali 1:25 000, arkusz Złoty Stok (in Polish). Wyd. Geol., Warszawa.

Cymerman, Z., 1996. The Złoty Stok-Trzebieszowice regional shear zone: the boundary of terranes in the Góry Złote Mts. (Sudetes). Geological Quarterly, 40 (1): 89-118.

Devasia, P., Natarajan, K., 2010. Adhesion of Acidithiobacillus ferrooxidans to mineral surfaces. International Journal of Mineral Processing, 94: 135-139.

Drahota, P., Filippi, M., 2009. Secondary arsenic minerals in the environment: a review. Environment International, 35: 1243-1255.

Drewniak, L., Matlakowska, R., Rewerski, B., Sklodowska, A., 2010. Arsenic release from gold mine rocks mediated by the activity of indigenous bacteria. Hydrometallurgy, 104: 437-442.

Drewniak, L., Maryan, N., Lewandowski, W., Kacyanowski, S., Sklodowska, A., 2012. The contribution of microbial mats to the arsenic geochemistry of an ancient gold mine. Environmental Pollution, 162: 190-201.

Dumańska-Słowik, M., Pieczka, A., Natkaniec-Nowak, L., Kunecki, P., Gaweł, A., Heflik, W., Smoliński, W., Kozub-Budzyń, G., 2018. Mg-enriched erythrite from Bou Azzer, Anti-Atlas Mountains, Marocco: geochemical and spectroscopic characteristics. Mineralogy and Petrology, 112: 381-392.

Dziekoński, T., 1972. Exploitation and ore metallurgy in the Lower Silesia from XIII to XXc (in Polish with English summary). Polska Akademia Nauk. Instytut Historii Kultury Materialnej. 4. Ossolineum. Wrocław.

Foster, A.L., Brown, Jr., G.E., Tingle, T.N., Parks, G.A., Voigt, D.E., Brantley, S.L., 1997. XAFS determination of As speciation in weathered mine tailings and contaminated soil from California, USA. Journal de Physique IV (Proceedings), 7: 815-816.

Frost, L.R., Marten,s, W., Williams, P.A., Kloprogge, T.J., 2003. Raman spectroscopic study of the vivianite arsenate minerals. Journal of Raman Spectroscopy, 34: 751-759.

Gas 'kova, O.L., Shironosova, G.P., Bortnikova, S.B., 2008. Thermodynamic estimation and stability field of bukovskýite, an iron sulfoarsenate. Geochemistry International, 46: 85-91.

Gil, G., Barnes, J.D., Boschi, C., Gunia, P., Raczyński, P., Szakmány, G., Bendő, Z., Péterdi, B., 2015. Nephrite from Złoty Stok (Sudetes, SW Poland): petrological, geochemical, and isotopic evidence for a dolomite-related origin. Canadian Mineralogist, 53: 533-556.

Haffert, L., Crow, D., 2008. Mineralogical controls on environmental mobility of arsenic from historic mine processing residues, New Zealand. Applied Geochemistry, 23: 1467-1483.

Haffert, L., Crow, D., Pope, J., 2010. Climatic and compositional controls on secondary arsenic mineral formation in high-arsenic mine wastes, South Island, New Zealand. New Zealand Journal of Geology and Geophysics, 53: 91-101.

Holmes, P.R., Crundwell, F.K., 2000. The kinetics of the oxidation of pyrite by ferric ions and dissolved oxygen: an electrochemical study. Geochimica et Cosmochimica Acta, 64: 263-274.
Jones, R.A., Koval, S.F., Nesbitt, H.W., 2003. Surface alteration of arsenopyrite (FeAsS) by Thiobacillus ferrooxidans. Geochimica et Cosmochimica Acta, 67: 955-965.

Juillot, F., Ildefonse, Ph., Morin, G., Calas, G., Kersabiec, A.M., Benedetti, M., 1999. Remobilization of arsenic from buried wastes at an industrial site: mineralogical and geochemical control. Applied Geochemistry, 14: 1031-1048.

Kato, A., Matsubara, S., Nagashima, K., Nakai, I., Shimizu, M., 1984. Kaňkite from the Suzukura mine, Enzan city, Yamanashi Prefecture, Japan. Mineralogical Journal, 12: 6-14.

Kocourková, E., Cempírek, J., Losos, Z., 2011a. Kaňkit z Dlouhé Vsi u Havlíčkova Brodu (in Czech). Acta rerum naturalium, 4: 7-12.

Kocourková, E., Sracek, O., Houzar, S., Cempírek, J., Losos, Z., Filip, J., Hršelová, P., 2011b. Geochemical and mineralogical control on the mobility of arsenic in a waste rock pile at Dlouhá Ves, Czech Republic. Journal of Geochemical Exploration, 110: 61-73.

Kowalski, W., 1969. Ore minerals from Złoty Stok (Lower Silesia) (in Polish with English summary). Prace Mineralogiczne, 16: 23-40.

Krause, E., Ettel, V.A., 1989. Solubilities and stabilities of ferric arsenate compounds. Hydrometallurgy, 22: 311-337.

Kubisz, J., 1964. Studium minerałów grupy ałunitu - jarosytu. Prace Geologiczne Komitetu Nauk Geologicznych, Polska Akademia Nauk, Oddział w Krakowie, 22: 1-96.

Langmuir, D., Mahoney, J., MacDonald, A., Rowson, J., 1999. Predicting arsenic concentrations in the porewaters of buried uranium mill tailing. Geochimica et Cosmochimica Acta, 63: 3379-3394.

Langmuir, D., Mahoney, J., Rowson, J., 2006. Solubility products of amorphous ferric arsenate and crystalline scorodite $\left(\mathrm{FeAsO}_{4}\right.$ $2 \mathrm{H}_{2} \mathrm{O}$ ) and their application to arsenic behavior in buried mine tailings. Geochimica et Cosmochimica Acta, 70: 2942-2956.

Ledbetter, R.N., Connon, S.A., Neal, A.L., Dohnalkova, A., Magnuson, T.S., 2007. Biogenic mineral production by a novel arsenic-metabolizing thermophilic bacterium from the Alvord Basin, Oregon. Applied and Environmental Microbiology, 73: $5928-5936$.

Mahoney, J., Slaughter, M., Langmuir, D., Rowson, J., 2007. Control of As and Ni release from a uranium mill tailings neutralization circuit: Solution chemistry, mineralogy and geochemical modeling of laboratory study results. Applied Geochemistry, 22: 2758-2776.

Majzlan, J., Drahota, P., Filippi, M., Grevel, K-D., Kahl, W-A., Plášil, J., Boerio-Goates, J., Woodfield, B.F., 2012a. Thermodynamic properties of scorodite and parascorodite $\left(\mathrm{FeAsO}_{4}\right.$ $\left.2 \mathrm{H}_{2} \mathrm{O}\right)$, kaňkite $\left(\mathrm{FeAsO}_{4} \cdot 3,5 \mathrm{H}_{2} \mathrm{O}\right)$, and $\mathrm{FeAsO}_{4}$. Hydrometallurgy, 117-118: 47-56.

Majzlan, J., Lazic, B., Armbruster, T., Johnson, M.B., White, M.A., Fisher, R.A., Plašil, J., Loun, J., Škoda, R., Novák, M., 2012b. Crystal structure, thermodynamic properties, and paragenesis of bukovskýite, $\mathrm{Fe}_{2}\left(\mathrm{AsO}_{4}\right)\left(\mathrm{SO}_{4}\right)(\mathrm{OH}) 9 \mathrm{H}_{2} \mathrm{O}$. Journal of Mineralogical and Petrological Sciences, 107: 133-148.

Majzlan, J., Drahota, P., Filippi, M., 2014. Parageneses and crystal chemistry of arsenic minerals. Reviews in Mineralogy and Geochemistry, 77: 17-184.

Majzlan, J., Amoako, F.Y., Kindlova, H., Drahota, P., 2015. Thermodynamic properties of zykaite, a ferric sulfoarsenate. Applied Geochemistry, 61: 294-301.

Makreski, P., Stefov, S., Pejov, L., Jovanowski, G., 2015. Theoretical and experimental study of the vibrational spectra of (para)symplesite and hörnesite. Spectrochimica Acta Part A; Molecular and Biomolecular Spectroscopy, 144: 155-162.

MandI, M., Vyskovsky, M., 1994. Kinetics of arsenic (III) oxidation by iron (III) catalyzed by pyrite in the presence of Thiobacillusferrooxidans. Biotechnology Letters, 16: 1199-1204.

MarkI, G., Marks, M.A.W., Derrey, I., Gührig, J-E., 2014. Weathering of cobalt arsenides: natural assemblages and calculated 
stability reactions among secondary Ca-Mg-Co arsenates and carbonates. American Mineralogist, 99: 44-56.

Marszałek, H., Wąsik, M., 2000. Influence of arsenic-bearing gold deposit on water quality in Zloty Stok mining area (SW Poland). Environmental Geology, 39: 888-892.

Mazur, S., Aleksandrowski, P., Kryza, R., Oberc-Dziedzic, T., 2006. The Variscan orogen in Poland. Geological Quarterly, 50 (1): 89-118.

Mikulski, S.Z., 1996. Gold mineralization within contact-metamorphic and shear zones in the "Zloty Jar" quarry - the Zloty Stok As-Au deposit area (Sudetes). Geological Quarterly, 40 (3): 407-442.

Mikulski, S.Z., Speczik, S., 2008. Organic and inorganic geochemistry of gold mineralization at the Zloty Stok, SW Poland. Applied Earth Science, 117: 149-159.

Mikulski, S.Z., Speczik, S., 2016. The auriferous ore mineralization and its zonal distribution around the Variscan Kłodzko-Złoty Stok granitoid pluton in the Sudetes (SW Poland) - an overview. Geological Quarterly, 60 (3): 650-674

Mikulski, S.Z., Williams, I.S., 2014. Zircon U-Pb ages of granitoid apophyses in the western part of the Kłodzko-Złoty Stok Granite Pluton (SW Poland). Geological Quarterly, 58 (2): 251-262.

Mikulski, S.Z., Williams, I.S., Bagiński, B., 2013. Early Carboniferous (Visean) emplacement of the collisional Klodzko-Złoty Stok granitoids (Sudetes, SW Poland): constraints from geochemical data and zircon U-Pb ages. International Journal of Earth Sciences, 102: 1007-1027.

Moses, C.O., Nordstrom, D.K., Herman, J.S., Mills, A.L., 1987. Aqueous pyrite oxidation by dissolved oxygen and by ferric iron. Geochimica et Cosmochimica Acta, 51: 1561-1571.

Muszer, A., 2011. Gold at Złoty Stok - history, exploitation, characteristic and perspectives. Archivum Mineralogiae Monograph, 2: 45-62.

Newman, D.K., Beveridge, T.J., Morel, F.M.M., 1997. Precipitation of arsenic trisulfide by Desulfotomaculum auripigmentum. Applied and Environmental Microbiology, 63: 2022-2028.

Nicholas, D.R., Ramamoorthy, S., Palace, V., Spring, S., Moore J.N., Rozenzweig, F., 2003. Biogeochemical transformations of arsenic in circumneutral freshwater sediments. Biodegradation, 14: 123-137

Ondruš, P., Veselovský, F., Hloušek, J., 1997a. A review of mineral associations and paragenetic groups of secondary minerals of the Jáchymov (Joachimsthal) ore district. Journal of Czech Geological Society, 42: 109-114.

Ondruš, P., Veselovský, F., Hloušek, J., Skála, R., Vavřín, I., Frýda, J., Čejka, J., Gabašová, A., 1997b. Secondary minerals of the Jáchymov (Joachimsthal) ore district. Journal of Czech Geological Society, 42: 3-76.

Paktunc, D., Bruggeman, K., 2010. Solubility of nanocrystalline scorodite and amorphous ferric arsenate: implications for stabilization of arsenic in mine wastes. Applied Geochemistry, 25 674-683.

Paktunc, D., Dutrizac, J., Gertsman, V., 2008. Synthesis and phase transformations involving scorodite, ferric arsenate and arsenical ferrihydrite: implications for arsenic mobility. Geochimica et Cosmochimica Acta, 72: 2649-2672.

Parafiniuk, J., Siuda, R., 2006. Schwertmannite precipitated from acid mine drainage in the Western Sudetes (SW Poland) and its arsenate sorption capacity. Geological Quarterly, 50 (4): 475-486.

Parviainen, A., Lindsay, M.B.J., Perez-Lopez, R., Gibson, B.D., Ptacek, C.J., Blowes, D.W., Loukola-Ruskeeniemi, K., 2012.
Arsenic attenuation in tailings at a former Cu-W-As mine, SW Finland. Applied Geochemistry, 27: 2289-2299.

Qin, W., Liu, K., Diao, M., Wang, J., Zhang, Y., Yang, C., Jiao, F., 2013. Oxidation of arsenite (As(III)) by ferric ion in the presence of pyrite and mixed moderately thermophilic culture. Hydrometallurgy, 137: 53-59.

Robins, R.G., 1987. Solubility and stability of scorodite, $\mathrm{FeAsO}_{4}$ $2 \mathrm{H}_{2} \mathrm{O}$ : discussion. American Mineralogist, 72: 842-844.

Rodriguez-Freire, L., Sierra-Alvarez, R., Root, R., Chorover, J., Field, J.A., 2014. Biomineralization of arsenate to arsenic sulfides in greatly enhanced at mildly acidic conditions. Water Research, 66: 242-253.

Rodriguez-Freire, L., Moore, S.E., Sierra-Alvarez, R., Root, R.A., Chorover, J., Field, J.A., 2016. Arsenic remediation by Formation of arsenic sulfide minerals in a continuous anaerobic bioreactor. Biotechnology and Bioengineering, 113: 522-530.

Schippers, A., Jozsa, P., Sand, W., 1996. Sulfur chemistry in bacterial leaching of pyrite. Applied and Environmental Microbiology, 62: 3424-3431.

Smulikowski, K., 1979. Polymetamorphic evolution of the crystalline complex of Śnieżnik and Góry Złote Mts in the Sudetes (in Polish with English summary). Geologia Sudetica, 14: 7-76.

Tomczyk-Żak, K., Kaczanowski, S., Drewniak, Ł., Dmoch, Ł., Sklodowska, A., Zielenkiewicz, U., 2013. Bacteria diversity and arsenic mobilization in rock biofilm from an ancient gold and arsenic mine. Science of the Total Environment, 461-462: 330-340.

Tu, Z., Guo, Ch., Zhang, T., Lu, G., Wan, J., Liao, Ch., Dang, Z., 2017. Investigation of intermediate sulfur species during pyrite xidation in the presence and absence of Acidithiobacillus ferrooxidans. Hydrometallurgy, 167: 58-65.

Vera, M., Schippers, A., Sand, W., 2013. Progress in bioleaching: fundamentals and mechanisms of bacterial metal sulfide oxidation - part A. Applied Microbiology and Biotechnology, 97: 7529-7541.

Voigt, D.E., Brantley, S.L., Hennet, R.J-C., 1996. Chemical fixation of arsenic in contaminated soils. Applied Geochemistry, 11: 633-643.

Walker, F.P., Schreiber, M.E., Rimstidt, J.D., 2006. Kinetics of pyrite oxidative dissolution by oxygen. Geochimica et Cosmochimica Acta, 70: 1668-1676.

Wiertz, J.V., Mateo, M., Escobar, B., 2006. Mechanism of pyrite catalysis of $\mathrm{As}(\mathrm{III})$ oxidation in bioleaching solutions at $30^{\circ} \mathrm{C}$ and $70^{\circ} \mathrm{C}$. Hydrometallurgy, 83: 35-39.

Wierzchołowski, B., 1976. Granitoids of the Kłodzko-Złoty Stok massif and their contact influence on the country rocks (petrographic characteristics) (in Polish with English summary). Geologia Sudetica, 11: 3-143.

Yuan, T.C., Jia, Y.F., Demopoulos, G.P., 2005. Synthesis and solubility of crystalline annabergite $\left(\mathrm{Ni}_{3}\left(\mathrm{AsO}_{4}\right)_{2} \cdot 8 \mathrm{H}_{2} \mathrm{O}\right.$. Canadian Metallurgical Quarterly, 44: 449-456.

Yu, J.Y., Park, M., Kim, J., 2002. Solubilities of synthetic schwertmannite and ferrihydrite. Geochemical Journal, 35: 119-132.

Zhu, Y.N., Zhang, X.H., Chen, Y.D., Zeng, H.H., Liu, J., Liu, H.L., Wang, X.M., 2013. Characterization, dissolution and solubility of synthetic erythrite $\left[\mathrm{CO}_{3}\left(\mathrm{AsO}_{4}\right)_{2} \cdot 8 \mathrm{H}_{2} \mathrm{O}\right]$ and annabergite $\left[\mathrm{Ni}_{3}\left(\mathrm{AsO}_{4}\right)_{2} 8 \mathrm{H}_{2} \mathrm{O}\right]$ at $25 \mathrm{C}$. Canadian Metallurgical Quarterly, 51: 7-17.

Żelaźniewicz, A., Aleksandrowski, P., Buła, Z., Karnkowski, P.H., Konon, A., Oszczypko, N., Ślączka, A., Żaba, J., Żydko, K., 2011. Regionalizacja tektoniczna Polski (in Polish). Komitet Nauk Geologicznych PAN, Wrocław. 